\title{
Analysing Corporate Insolvency in the Gulf Cooperation Council using Logistic Regression and Multidimensional Scaling
}

\begin{abstract}
Purpose: This paper examines corporate insolvency in the Gulf Cooperation Council (GCC) region for the period 2004-2011.

Design/methodology/approach: Financial ratio data on 56 matched pairs of insolvent and solvent firms are analysed using logistic regression with best-subset selection criteria to identify significant ratios, and prediction accuracy is tested on an ex-ante sample. The main dimensions of ratios, and the weights that firms attach to them, are examined using 3-way Multidimensional Scaling (MDS).

Findings: A parsimonious Logit model comprising one profitability, one leverage and two cash flow ratios has accuracy levels of $84.4 \%$ overall, 95.6\% type I and 73.9\% type II. Four financial-ratio dimensions are extracted from the MDS: (i) 'Non-strategic sales activities', (ii) 'Profitability and financial stability balance', (iii) 'Sales activities against capital conversion'; and (iv) 'Market value against cash generation’. Insolvent firms appear very specific and attach most salience to the 'Non-strategic sales activities' dimension; unlike solvent firms which attach more salience to the other three dimensions.
\end{abstract}

Practical Implications: Results indicate profitability ratios should be included in GCC insolvency classification models. It is suggested that firms' managers should focus less on non-strategic sales activities to reduce susceptibility to insolvency.

Originality/value: The study provides empirical evidence on insolvency in the GCC and introduces the application of 3-way MDS to insolvency research in the region.

Keywords: Gulf Cooperation Council, Corporate insolvency, Multidimensional Scaling, Cluster analysis, Logit, Probit, Financial ratio 


\section{Introduction}

The stock exchange markets of the Gulf Cooperation Council (GCC) region (Bahrain, Saudi Arabia, Oman, Qatar and the United Arab Emirates) are important to the Middle East and North Africa (MENA). They constitute half of MENA's listed companies and three-quarters of the MENA region's market capitalisation (Rocha and Farazi, 2011). Beyond MENA, GCC economies contribute significantly to the global economy by investing their oil incomes abroad (Peeters, 2011); yet it was not until the 1980s that GCC countries began to regulate their stock markets (Al-Ajmi and Kim, 2012). GCC countries were only able to limit the negative effects of the 2008 global financial crisis by employing financial-sector support and countercyclical measures using the financial reserves they had accumulated during the oil price boom period of 2003-2008 (Khamis and Senhadji, 2010). The 2008 crisis revealed many vulnerabilities in the GCC region (Khamis and Senhadji, 2010). GCC financial markets are particularly vulnerable to firm insolvency (Uttamchandani et al., 2009); this is an international problem with high economic, financial and social cost (Warner, 1977, Altman, 2006, Lensberg et al., 2006, Brigham and Ehrhardt, 2010). It can impact on the investors or owners; creditors, employees and other stakeholders (Deakin, 1972, White, 1996, Morris, 1997, Moyer et al., 2008). Hence there is a need for research that can cast light on the susceptibility of GCC firms to insolvency. Such insight can aid investment decisions as well as offer a strategic guide to firms' managers.

There are important differences between the GCC and other major trading blocs, such as the European Union (EU) and the North American Free Trade Agreement (NAFTA). GCC economies remain highly dependent on oil, and are less diversified (Fasano and Zubair, 2003). GCC stock markets are less mature and, despite recent liberalisation measures, continue to be less liberal and not efficient in the weak form (Arouri et al., 2011, Al-Ajmi and Kim, 2012). The GCC financial and regulatory frameworks are less harmonised (Hussain et al., 2002), and the GCC is also culturally distant (House et al., 2004). Insolvency research evidence based on other regions may thus be misleading when applied directly to GCC firms: GCC context-specific research 
is required to examine both the commonalities and differences between GCC insolvency and other regions.

Compared to other regions, insolvency research in the GCC is relatively nascent, dating back to the 1990s, not the 1960s as in other regions. With the exception of Basheikh (2012) who applied logistic regression, the few studies that have been conducted have relied on Altman's (1968) Discriminant Analysis (MDA) technique, despite its restrictive assumptions. Second, although GCC studies have used a number of financial ratios to study insolvency (e.g. profitability, liquidity, leverage and activity ratios), they have not yet examined the valuable information generated by the operating cash flow, which, as shown by research in other contexts, is useful for predicting financial distress. There are thus three areas of weakness in GCC insolvency research: the volume of research is small; the scope of methodologies applied is narrow; and unlike other contexts, the predictive value of operating cash flow has not been examined. Focusing on firms listed on GCC stock markets between 2004 and 2011, this study hopes to contribute to the literature in these three areas. As well as logistic regression, we introduce the application of the multidimensional scaling (MDS) technique to insolvency research in the GCC context. MDS enables the visualisation of key differences between insolvent and solvent firms, increasing the depth of insight acquired (Neophytou and Molinero, 2004b). We also examine the predictive capacity of operating cash flow information in the GCC context.

The rest of this paper is structured as follows. In section two, we review the literature on financial failure in the GCC context as well as literature on financial failure prediction techniques, and we state our research questions based on this review. In section three, we describe the methods and the data used to answer the research question. In section four, we present the results. In section five, we discuss the implications of the results for investors and managers, before concluding the study.

\section{Literature review and research questions}

To predict insolvency, it is necessary to understand what causes it. Charan et al. (2002) argue that firms fail because they are poorly managed. Altman (1983) states that the overwhelming cause of an individual firm's failure is some type of managerial 
incompetence. Goudie and Meeks (1991) examine the extent to which macro-economic factors can be held responsible for the failure of large companies in turbulent exchange regimes. They conclude that factors that are beyond the control of the management, such as external macro-economic factors, often play a substantial role in failure and give results that offer a corrective to the wide spread notion that the prime cause of failure is bad management.

It is clear that environmental factors can instigate failure. For example, despite governments and their central banks infusing liquidity into the financial system via repurchase agreements and offering direct liquidity injections through long-term deposit schemes, the GCC region experienced many corporate failures following the financial crisis in 2008 (Khamis and Senhadji, 2010). The drop in oil prices in late 2009 was another shock. It resulted in the 'Dubai debt crisis', further weakening GCC capital markets (Khamis and Senhadji, 2010, Onour, 2010). Similarly, efficient markets reward or punish firms based on performance: Many studies conducted within the region have concluded that not all the GCC markets are efficient (Al-Khazali et al., 2007, Bley, 2011, Al-Ajmi and Kim, 2012). Failing, poorly managed firms can thus continue to operate without market censure until it is too late.

Environments being equal, however, weaker, less well-managed firms will exhibit poorer health. Financial ratios are important here: evidence shows that both the level (Chen and Shimerda, 1981) and trend over time (Neophytou and Molinero, 2005) of financial ratios can reveal the state of health of a firm. However, the relative importance of the ratios is not clear; studies differ in which ratios they consider significant (Chen and Shimerda, 1981, Barnes, 1987). This is true generally as well as, more specifically, in the GCC context. For example, in the GCC context, Hasabo (1987) suggested that total asset to ownership equity, shareholders equity to paid capital and profit from other operations to total profit are important; whereas Basheikh (2012) found return on investment, retained earnings to total assets, fixed assets to ownership equity, asset turnover and ownership equity turnover important.

Of the different types of ratios, the level of importance of cash flow ratios is perhaps the most unclear. Cash flow statements indicate a firm's cash receipts and 
payments from operational activities (CFA institute, 2009). The importance of the cash flow information as a predictive tool derives from the power of cash to enable a firm to meet its obligations and continue to operate (Gilbert et al., 1990). A number of studies have tested this hypothesis. As early as 1966, Beaver's research suggested that cash flow from operations to total debt ratio was very accurate at predicting failure a year before it occurred; and a number of studies since (Blum, 1974, Smith and Liou, 1979, Mensah, 1984, Aziz et al., 1988, Aziz and Lawson, 1989, Gilbert et al., 1990, Charitou et al., 2004) have concluded that cash flow ratios add explanatory power. Ward (1994) posited that cash flow information was more useful in some industries (mining, oil and gas) than others. Gombola and Ketz (1983), in one of the earliest studies to incorporate incremental operating cash flow, suggested that operating cash flow provides more information than that which exists in most other ratios. Similarly, Gentry et al. (1987) found that cash flow-based ratios can improve the scope and accuracy of prediction models; and Gilbert et al. (1990) who suggested that cash flow information can provide a more reliable means for assessing the financial health. Not all evidence is in agreement, however: Casey and Bartczak (1985) found that operating cash flow ratios have no incremental predictive power over accrual-based ratios. We were not able to find publications in the GCC context on the importance of cash flow ratios.

To summarise, then, studies in the GCC context are not only unclear on which ratios are important but have also yet to test the importance of cash flow information. Motivated by this gap, our first research question was thus:

\section{RQ1: What are the significant predictors of insolvency in the GCC region; and do they include cash flow-based ratios?}

A number of techniques for predicting insolvency with financial ratios have been developed over the last 50 years. The first was Beaver's (1966) single predictor, univariate model. Altman (1968) demonstrated the insufficiency of Beaver's single predictor model and proposed instead the multiple-predictor, Multiple Discriminant Analysis (MDA) technique. Regarded as seminal, Altman's (1968) MDA technique has been widely applied and further developed by a number of researchers (Deakin, 1972, Edmister, 1972, Wilcox, 1973, Blum, 1974, Libby, 1975). Despite its popularity, MDA 
has been criticised for a number of assumptions it makes (Edmister, 1972, Zavgren, 1983, Karels and Prakash, 1987). It has two key restrictive statistical assumptions (Balcaen and Ooghe, 2006): multivariate normality of financial ratios and equal variance-covariance matrices across groups - but research shows that both assumptions are often violated (Richardson and Davidson, 1983, Ezzamel et al., 1987, Laitinen and Kankaanpaa, 1999). The predictive accuracy of MDA can also be significantly reduced when optimal conditions for its application are not met by neglecting the prior probabilities of failure and not defining an accurate cut-off score (Edmister, 1972, Joy and Tollefson, 1975, Ohlson, 1980, Balcaen and Ooghe, 2006). To avoid some of the limitations of MDA, Ohlson (1980) introduced logistic regression: it does not require multivariate normality, or equality of variance-covariance matrices, and no assumptions are made about prior probabilities of failure (Ohlson, 1980, Zavgren, 1983).

There have been further methodological developments since since Ohlson (1980) including decision trees (Friedman, 1977); neural networks (Salchenberger et al., 1992, Coats and Fant, 1993); genetic algorithms (Varetto, 1998, Shin and Lee, 2002) and survival analysis (Lane et al., 1986, Luoma and Laitinen, 1991). Despite these advances, Altman's (1968) model has dominated GCC insolvency research (Aldeehani, 1995, AlShebani, 2006). Some studies have applied Altman's model in its original form (Aldeehani, 1995, AlShebani, 2006); others with minor modifications in terms of predictors (Abudelrahman, 2004, Basheikh, 2012). The exception is Basheikh’s (2012) logistic regression application. We can argue thus that GCC insolvency research has been dominated by a very limited number of techniques.

The current study aims to contribute towards filling this gap by applying multidimensional scaling (MDS), a new approach and philosophy in GCC insolvency research. MDS is a multivariate visualisation technique that attempts to find a solution by locating objects in a spatial configuration or graphical representation (Kruskal and Wish, 1978, Schiffman et al., 1981). Although traditionally a social sciences approach, MDS has been applied in the accounting, finance and banking disciplines as an alternative to the more traditional statistical techniques when the data do not satisfy parametric assumptions (Moriarity and Barron, 1976, Emery et al., 1982). Mar 
Molinero and Ezzamel (1991) extended MDS to insolvency research in the UK. It has been shown that the visualisation of the patterns in financial ratios that MDS offers can help identify the reasons behind firms’ poor (or good) financial health (Mar-Molinero and Serrano-Cinca, 2001, Neophytou and Molinero, 2004b). It is this visualisation capability that makes MDS particularly useful in studying insolvency as it can provide insight on the level of similarity (or dissimilarity) between firms by visualising the distances between insolvent and solvent firms; or the level of similarity (or dissimilarity) between financial ratios. Applied in the latter regard, the key dimensions of financial ratios can be extracted and, subsequently, reasons behind a firm's financial health can be revealed by studying the relative salience that solvent and insolvent firms attach to the extracted financial ratio dimensions. Thus, based on these arguments, our second and third research questions were:

\section{RQ2: What are the key financial ratio dimensions in the GCC?}

RQ3: Relatively, what are the differences between solvent and insolvent firms in the salience they attach to financial ratio dimensions?

\section{Methods}

\subsection{Sampling and data collection}

Data on solvent and insolvent firms were gathered from DataStream ${ }^{\mathrm{TM}}$, financial statements and company websites. Categorising firm failure is crucial in all insolvency studies. Altman and Narayanan (1997) suggest the definition of failure in the literature varies 'depending on the inclination of the researcher or on the local conditions'. In this study, we adopted the legal definition of corporate failure in the GCC region. Under the law, in most GCC countries, firms are considered 'failed' if accumulated losses reach or exceed 75\% of capital (Saudi Commerce Ministry, 1966, United Arab Emirate Ministry of Economy, 1984, Sultanate of Oman Ministry of Commerce and Industry, 1986, Ministry of Industry and Commerce Kingdom of Bahrain, 2002, State of Qatar Ministry of Economy and Commerce, 2002). The exception is the Kuwaiti system where the law mandates that a company increases its capital accordingly in order to continue trading if accumulated losses reach 25\% of capital (Kuwait stock exchange, 2010). 
As discussed above, external factors can trigger or exacerbate failure. So to examine the managerial (internal) causes of failure, it is now accepted practice to control for external influences by matching each sampled insolvent firm with an equivalent solvent firm, as shown in Appendix I. We matched firms using the most popular criteria in the literature (Mar Molinero and Ezzamel, 1991); (i) region, (ii) industry sector, (iii) comparable asset size, and (iv) financial year. Using data between 2004 and 2011, we found 56 matching pairs or 112 firms. For each insolvent firm (and matching solvent firm), financial data were collected for the year before failure. Table 1 shows the number of firms sampled in each sector by country. Also shown in brackets are the average asset values in US dollars (World Bank mid-year conversion rate) of the firms sampled in each sector and country. Our sample covers eight sectors: concurring with previous studies (Gilbert et al., 1990) banks, financial investment, insurance and real estate firms were excluded from the sample because of the different and unique nature of the financial reports in these sectors. In some sectors, there were a limited number of companies in the same country, so we matched firms by sector regardless of home country.

Table 1 Sample of insolvent/solvent firms by sector and country

\begin{tabular}{|c|c|c|c|c|c|c|c|}
\hline \multicolumn{8}{|c|}{ Sample of Insolvent Firms: Sector by Country } \\
\hline Sector & \multicolumn{7}{|c|}{ Country } \\
\hline & Bahrain & Kuwait & Oman & Qatar & $\begin{array}{l}\text { Saudi } \\
\text { Arabia }\end{array}$ & UAE & Total \\
\hline Agriculture & 0 & 1 & 8 & 0 & 3 & 2 & 14 \\
\hline Construction & 0 & 4 & 2 & 0 & 0 & 1 & 7 \\
\hline Hotel and Tourism & 1 & 3 & 1 & 0 & 0 & 0 & 5 \\
\hline Industrial Investment & 0 & 0 & 2 & 0 & 6 & 1 & 9 \\
\hline Petrochemical Industries & 0 & 3 & 0 & 0 & 0 & 0 & 3 \\
\hline Retail and Services & 0 & 6 & 3 & 1 & 1 & 0 & 11 \\
\hline Telecommunications & 0 & 0 & 0 & 0 & 1 & 0 & 1 \\
\hline Transportation & 0 & 3 & 0 & 0 & 3 & 0 & 6 \\
\hline Total & 1 & 20 & 16 & 1 & 14 & 4 & 56 \\
\hline \multicolumn{8}{|c|}{ Sample of Solvent Firms: Sector by Country } \\
\hline Sector & \multicolumn{7}{|c|}{ Country } \\
\hline & Bahrain & Kuwait & Oman & Qatar & $\begin{array}{l}\text { Saudi } \\
\text { Arabia }\end{array}$ & UAE & Total \\
\hline Agriculture & 0 & 1 & 8 & 0 & 2 & 3 & 14 \\
\hline Construction & 0 & 4 & 2 & 0 & 0 & 1 & 7 \\
\hline Hotel and Tourism & 1 & 3 & 1 & 0 & 0 & 0 & 5 \\
\hline Industrial Investment & 0 & 5 & 2 & 0 & 1 & 1 & 9 \\
\hline Petrochemical Industries & 0 & 3 & 0 & 0 & 0 & 0 & 3 \\
\hline
\end{tabular}




\begin{tabular}{|l|l|l|l|l|l|l|l|}
\hline Retail and Services & 0 & 6 & 3 & 1 & 1 & 0 & $\mathbf{1 1}$ \\
\hline Telecommunications & 0 & 0 & 0 & 0 & 1 & 0 & $\mathbf{1}$ \\
\hline Transportation & 0 & 5 & 0 & 0 & 1 & 0 & $\mathbf{6}$ \\
\hline Total & $\mathbf{1}$ & $\mathbf{2 7}$ & $\mathbf{1 6}$ & $\mathbf{1}$ & $\mathbf{6}$ & $\mathbf{5}$ & $\mathbf{5 6}$ \\
\hline
\end{tabular}

We selected 28 financial ratios according to Beaver's (1966) selection criterion, i.e. ratios most commonly and successfully used in prior studies (Beaver, 1966, Altman, 1968, Deakin, 1972, Elam, 1975, Gombola and Ketz, 1983, Mensah, 1983, Dambolena and Khoury, 2012). The financial ratios, shown in table 2, cover six major categories: profitability, leverage, liquidity, activity, operating cash flow and markets. As discussed earlier, we included cash flow ratios in order, for the first time, to examine their predictive significance in the GCC context. We did not include the ratio EBITTA (Earnings to total assets) because the calculation of this ratio closes resembles the rule used to classify firms as solvent or insolvent.

Table 2 Definition of Financial ratios and summary statistics by failure category

\begin{tabular}{|c|c|c|c|c|c|c|c|c|}
\hline \multicolumn{3}{|c|}{ Description } & \multicolumn{6}{|c|}{ Descriptive Statistics By (Firm) Failure Category } \\
\hline $\begin{array}{l}\text { Ratio } \\
\text { Variable }\end{array}$ & Short Description & rmula & \multicolumn{2}{|c|}{ Ratio Mean } & \multicolumn{2}{|c|}{ Standard Deviation } & \multicolumn{2}{|c|}{$\begin{array}{l}\text { Coefficient of } \\
\text { variation }\end{array}$} \\
\hline \multicolumn{3}{|c|}{ Type of Firm (S = Solvent; INS = Insolvent) } & $\mathrm{S}$ & INS & $\mathrm{S}$ & INS & $\mathrm{S}$ & INS \\
\hline EBITSEQ & $\begin{array}{l}\text { Profitability - Return On } \\
\text { Equity }\end{array}$ & $\begin{array}{l}\text { Earnings Before Interest And } \\
\text { Taxes/Shareholders' Equity }\end{array}$ & 7.9 & -0.5 & 57.6 & 2.8 & 727.7 & -606.3 \\
\hline EBITCE & $\begin{array}{l}\text { Profitability - Return On } \\
\text { Capital Employed }\end{array}$ & $\begin{array}{l}\text { Earnings Before Interest And } \\
\text { Taxes/Capital Employed }\end{array}$ & 5.9 & -0.3 & 43.2 & 0.3 & 732.3 & -104.7 \\
\hline EBITS & $\begin{array}{l}\text { Profitability - EBIT } \\
\text { Margin }\end{array}$ & $\begin{array}{l}\text { Earnings Before Interest And } \\
\text { Taxes/Sales }\end{array}$ & 2.5 & -6.1 & 17.7 & 38.5 & 697.5 & -627.8 \\
\hline EBITTL & $\begin{array}{l}\text { Profitability - Earing To } \\
\text { Total Liabilities }\end{array}$ & $\begin{array}{l}\text { Earnings Before Interest And } \\
\text { Taxes/Total Liabilities }\end{array}$ & 6 & -0.4 & 42.9 & 0.6 & 714.4 & -132.8 \\
\hline$G P M$ & $\begin{array}{l}\text { Profitability - Gross } \\
\text { Profit Margin }\end{array}$ & Gross Profit/Sales & 25.5 & -23.5 & 19.2 & 230.3 & 75.5 & -979.2 \\
\hline RETA & $\begin{array}{l}\text { Leverage - Retained } \\
\text { Earnings To Total } \\
\text { Assets }\end{array}$ & $\begin{array}{l}\text { Retained Earnings/Total } \\
\text { Assets }\end{array}$ & 0 & -0.3 & 0.4 & 0.8 & 1572.2 & -253.4 \\
\hline SETA & $\begin{array}{l}\text { Leverage - Equity To } \\
\text { Total Assets }\end{array}$ & $\begin{array}{l}\text { Shareholders' Equity/Total } \\
\text { Assets }\end{array}$ & 53.6 & 39 & 26.4 & 37.6 & 49.3 & 96.3 \\
\hline SETL & $\begin{array}{l}\text { Leverage - Equity To } \\
\text { Total Liabilities }\end{array}$ & $\begin{array}{l}\text { Shareholders' Equity/Total } \\
\text { Liabilities }\end{array}$ & 2.6 & 2 & 3.2 & 4.1 & 122.2 & 209.6 \\
\hline TLTA & $\begin{array}{l}\text { Leverage - Total } \\
\text { Liabilities To Total } \\
\text { Assets }\end{array}$ & Total Liabilities/Total Assets & 1.1 & 3.3 & 1.7 & 9.2 & 156.5 & 275.3 \\
\hline TLNW & $\begin{array}{l}\text { Leverage - Total } \\
\text { Liabilities To Net Worth }\end{array}$ & Total Liabilities/Net Worth[1] & 4 & 4.5 & 4.9 & 13 & 122.7 & 286.7 \\
\hline SETD & $\begin{array}{l}\text { Leverage - Equity To } \\
\text { Debt }\end{array}$ & $\begin{array}{l}\text { Shareholders' Equity/Total } \\
\text { Debt }\end{array}$ & 0.4 & 0.6 & 0.3 & 0.4 & 58.2 & 62.5 \\
\hline$C R$ & $\begin{array}{l}\text { Liquidity - Current } \\
\text { Ratio }\end{array}$ & $\begin{array}{l}\text { Current Assets/Current } \\
\text { Liabilities }\end{array}$ & 2.2 & 1.8 & 2.4 & 2.2 & 110.4 & 123 \\
\hline$Q R$ & Liquidity - Quick Ratio & $\begin{array}{l}\text { (Current Assets - Stocks)/ } \\
\text { Current Liabilities }\end{array}$ & 1.4 & 1.3 & 1.7 & 1.7 & 114.3 & 137.3 \\
\hline WCTA & $\begin{array}{l}\text { Liquidity - Working } \\
\text { Capital To Total Assets }\end{array}$ & Working Capital/Total Assets & -0.5 & 0 & 4.8 & 0.4 & -928.6 & -3538.9 \\
\hline IT & $\begin{array}{l}\text { Activity - Inventory } \\
\text { Turnover }\end{array}$ & Cost Of Sales/Inventory & 8.9 & 14 & 13.3 & 47.7 & 148.7 & 340.4 \\
\hline TDS & Activity - Debt Ratio & Total Debt[2]/Sales & 1.6 & 13 & 4.4 & 84 & 273.7 & 644.7 \\
\hline
\end{tabular}




\begin{tabular}{|l|l|l|l|l|l|l|l|l|}
\hline AT & $\begin{array}{l}\text { Activity - Total Asset } \\
\text { Turnover }\end{array}$ & Sales/Total Assets & 0.6 & 0.6 & 0.5 & 0.7 & 83.4 & 111.5 \\
\hline SCA & $\begin{array}{l}\text { Activity - Sales To } \\
\text { Current Assets }\end{array}$ & Sales/Current Assets & 1.6 & 1.5 & 1.1 & 1.2 & 72.3 & 79.4 \\
\hline SFA & $\begin{array}{l}\text { Activity - Fixed Asset } \\
\text { Turnover }\end{array}$ & Sales/Fixed Assets & 1.9 & 2.6 & 2.9 & 6.8 & 153.5 & 261.6 \\
\hline SWC & $\begin{array}{l}\text { Activity - Working } \\
\text { Capital Turnover }\end{array}$ & Sales/Working Capital[3] & 0.4 & -6.5 & 15.2 & 75 & 3500.2 & -1153 \\
\hline CFFOTA & $\begin{array}{l}\text { Cash Flow - Cash Flow } \\
\text { On Assets }\end{array}$ & $\begin{array}{l}\text { Cash Flow From } \\
\text { Operations/Total Assets }\end{array}$ & 0.2 & 0 & 0.8 & 0.1 & 400.1 & -336.5 \\
\hline CFFOS & $\begin{array}{l}\text { Cash Flow - Cash flow } \\
\text { on Sales }\end{array}$ & $\begin{array}{l}\text { Cash Flow From } \\
\text { Operations/Sales }\end{array}$ & 12417.5 & -328.2 & 92753.9 & 1651.4 & 747 & -503.2 \\
\hline CFFOCL & $\begin{array}{l}\text { Cash Flow - Cash Flow } \\
\text { on Current Liabilities }\end{array}$ & $\begin{array}{l}\text { Cash Flow From } \\
\text { Operations/Current Liabilities }\end{array}$ & 1.2 & 0.1 & 5.7 & 0.7 & 462.3 & 1184.3 \\
\hline CFFOTL & $\begin{array}{l}\text { Cash Flow - Cash Flow } \\
\text { on Total Liabilities }\end{array}$ & $\begin{array}{l}\text { Cash Flow From } \\
\text { Operations/Total Liabilities }\end{array}$ & 0.7 & 0 & 3 & 0.4 & 425.6 & 1563 \\
\hline CFFONW & $\begin{array}{l}\text { Cash Flow - Cash Flow } \\
\text { on Net Worth }\end{array}$ & $\begin{array}{l}\text { Cash Flow From } \\
\text { Operations/Net Worth }\end{array}$ & 0.2 & -0.2 & 0.3 & 1 & 148.4 & -520.7 \\
\hline TDCFFO & $\begin{array}{l}\text { Cash Flow - Total Debt } \\
\text { To Cash Flow Ratio }\end{array}$ & $\begin{array}{l}\text { Total Debt/Cash Flow From } \\
\text { Operations }\end{array}$ & 3.2 & 81.1 & 5.2 & 512.9 & 161.8 & 632.8 \\
\hline MVOETD & $\begin{array}{l}\text { Market - Market Value } \\
\text { To Debt }\end{array}$ & $\begin{array}{l}\text { Market Value Of Equity/Total } \\
\text { Debt }\end{array}$ & 7.8 & 6.6 & 12.9 & 17.6 & 165.3 & 267.3 \\
\hline MVOESE & $\begin{array}{l}\text { Market - Market Value } \\
\text { To Equity }\end{array}$ & $\begin{array}{l}\text { Market Value Of } \\
\text { Equity/Shareholders' Equity }\end{array}$ & 1.9 & 1.7 & 1.4 & 5.3 & 76.9 & 312.7 \\
\hline $\begin{array}{l}\text { [1] Net Worth= total Assets-total Liability } \\
\text { [2] Total Debt=long-term Debt + short-term Debt + current portion of long-term Debt } \\
\text { [3] Working Capital =Current Asset - Current Liabilities }\end{array}$ & & & \\
\hline
\end{tabular}

\subsection{Data Analysis}

\section{Logistic Regression}

We used Logistic regression or Logit model to address RQ1. We chose the Logit model because it satisfies a number of important criteria. First, it does not have restrictive distributional assumptions. This is important because, beyond predictive capacity, we are interested in the statistical significance of ratios: P-values may be incorrect when distributional assumptions are violated. Tests showed that all 28 financial ratio variables are non-normal, with the p-value of the Shapiro-Wilk statistic less than 0.001 in all cases. The Mardia Skewness, Mardia Kurtosis and Henze-Zirkler statistics also had p-values less than 0.001, confirming lack of multivariate normality. Group homogeneity tests also indicated (chi-square $=3018$, d.f. $=406, p<.0001)$ that the covariance matrices of the insolvent and solvent firms cannot be considered equivalent. These results confirm that these financial ratio data are not suitable for MDA.

The second criterion is prediction accuracy: to be confident that the set of ratios found significant does contribute to 'good' predictions of GCC corporate 
insolvency, the prediction model must be 'good' overall. The performance of insolvency models is, typically, assessed by classification accuracy (Altman and Narayanan, 1997). Comparative studies suggest that Logit can perform at least as well as most other popular techniques: Whereas Charitou et al. (2004) ranked Logit second to neural networks (NN) and above MDA, Gloubos and Grammatikos (1988) found its overall accuracy on out-sample predictions higher than MDA, LPM (Linear probability model) and Probit. Laitinen and Kankaanpaa (1999) found Logit more accurate than five other popular techniques (including NN, recursive partitioning and MDA) in ex-ante predictions one year before failure occurred. Logit compares well even to more recent machine learning techniques such as Support Vector Machine (SVM) and Least Square Support Vector Machine (LSSVM); in personal credit classification comparisons, Zhu et al. (2013, p. 264)) ranked LSSVM first, logistic third and SVM fourth with their first test data. With their second test data, they ranked logistic first LSSVM fourth and SVM fifth.

The final criterion is interpretability: to address a lack in the literature, we wish to examine the significance of the effect of profitability ratios on insolvency in the GCC. Logit is highly interpretable (Steyerberg et al., 2001, Fedenczuk, 2003) as the estimated coefficients of the ratios can be translated directly into the effect of each ratio on the odds of insolvency. In contrast, a number of the techniques, namely NN, SVM and LSSVM, that sometimes perform better than Logit, are black box in nature and not interpretable (Doumpos et al., 2007, Han et al., 2013, Zhu et al., 2013). Classification trees are intuitive and interpretable but there is no evidence that they are more accurate than Logit: in Laitinen and Kankaanpaa (1999), overall, Logit outperformed Classification trees for all ex-ante predictions.

We ran the Logit model in SAS 9.2 setting the firm failure category as dependent (event $=$ 'insolvent') and the 28 financial ratios as predictors. We partitioned the data into a training set covering the period 2004-2009 (33 pairs or 66 cases) and a test set covering 2010-2011 (23 pairs or 46 cases). To avoid overfitting, it is generally accepted that a Logit model should have at least 10 cases per predictor (Peduzzi et al., 1996). Thus, with 66 cases in our training data set, we should fit a 
model with no more than six predictors. We examined the literature for guidance on how to choose the optimal set of six predictors. We found seven corporate insolvency studies that have applied the Logit model using a data set of similar size. As shown in table 3, except for Basheikh (2012), all seven studies apply explicit selection criteria. Some (Gentry et al., 1985, Peel et al., 1986, Ward, 1994) choose the ratios discretionarily based on prior evidence or theory; others choose the ratios empirically using algorithmic stopping rules (Keasey and McGuinness, 1990, Charitou et al., 2004) or based on the results of prior analysis with other statistical techniques such as principal components analysis (PCA) (Canbas et al., 2005). As we stated earlier, we chose the 28 ratios under consideration based on evidence from the literature. So we could not re-apply this strategy to further narrow down the set of candidate ratios. Equally, we could not use PCA because, once combined into components, it is impossible to isolate the effect of individual ratios; we would have been unable to assert whether cash flow ratios are important in the GCC and thus address RQ1 fully. Subsequently, we adopted the algorithmic approach; but unlike Charitou et al. (2004), and Keasey and McGuinness (1990), we did not use the stepwise, backward or forward criteria which have been shown to have a number of limitations (Steyerberg et al., 2001). Instead, we applied the best subset selection criterion using the SCORE option in SAS 9.2.

Table 3 Ratio selection strategies in logistic insolvency studies

\begin{tabular}{|l|l|l|}
\hline Study Details & $\begin{array}{l}\text { Estimation Data } \\
\text { (Insolvent/Solvent) }\end{array}$ & Ratio Selection Criteria \\
\hline $\begin{array}{l}\text { Charitou et al. } \\
(2004)\end{array}$ & $25 / 25$ & $\begin{array}{l}\text { Algorithmic: backward and forward } \\
\text { criteria }\end{array}$ \\
\hline $\begin{array}{l}\text { Gentry et al. } \\
(1985)\end{array}$ & $33 / 33$ & Predetermined based on theory \\
\hline Ward (1994) & $14 / 37$ & Predetermined based on literature \\
\hline Basheikh (2012) & $18 / 38$ & No explicit criteria \\
\hline $\begin{array}{l}\text { Keasey and } \\
\text { McGuinness (1990) }\end{array}$ & $43 / 43$ & Algorithmic: stepwise criterion \\
\hline Peel et al. (1986) & $34 / 44$ & Predetermined based on literature \\
\hline $\begin{array}{l}\text { Canbas et al. } \\
(2005)\end{array}$ & $18 / 22$ & $\begin{array}{l}\text { Step 1: ANOVA to select 12 ‘early } \\
\text { warning ratios’ } \\
\text { Step 2: PCA of selected ratios }\end{array}$ \\
\hline
\end{tabular}


Based on Furnival and Wilson's (1974) branch-and-bound algorithm, the SCORE method estimates a specified number of models for each given number of predictors. It is not a fool proof approach: the selected subsets are unstable, particularly with small data sets. To enable the selection of the most robust subset, we conducted the selection process by borrowing some elements from Breiman's (1996) 'bagging' procedure. First, as we have explained, our model should have no more than six predictors; so we investigated only subsets with six predictors. Second, taking random samples with replacement, we created 1000 bootstrap replicates of the training data set, each being of equal size to the original sample. For each replicate, we then ran logistic regression entering all 28 financial ratios as predictors and specified that a single model (i.e. best fitting model with the highest likelihood score statistic) using six predictors should be estimated. Third, we tested the predictive performance of the most frequent ( $>$ 1\%) subsets of the 1000 using the original training data set. We then evaluated the predictive performance of the most frequent subsets using the weighted value of the area under the curve (AUC) of the receiver operating characteristic curve (ROC), using each subset's frequency as the weight. Likened to the Gini coefficient (Thomas et al., 2002) and the Mann-Whitney-Wilcoxon test (Hanley and McNeil, 1982), the AUC is an important index for evaluating a model's ability to correctly forecast a dichotomous dependent with values ranging from 0.5 for a random classifier to 1 for a perfect classifier. Rather than as an absolute value measure, the AUC is most useful as a single number metric for comparing classification models as employed in this study.

Finally, using the subset with highest weighted AUC, we estimated the logistic regression model for the training data set. To validate the logistic model, we then used the estimated parameters of the significant ratios to score the test data set. As such we adopted a forecast validation test or out-of-sample, ex-ante test since our test data set is from a later period. According to Jones (1987), a forecast validation tests not only for overfitting which is likely to occur with in-sample validation but also the stationarity assumption, i.e. that relationship between ratios and failure holds over time. To further validate the results, we then re-ran the final model and validation test but this time using probit instead of logistic regression. 


\section{3-Way Multidimensional scaling with Hierarchical Cluster Analysis}

To address the second and third research questions, we employed 3-way MDS (Kruskal and Wish, 1978) to extract the key dimensions of the 28 financial ratios because (i) MDS does not carry restrictive distributional assumptions such as normality, equal variance-covariance structures or independence of ratios, and (ii) we can measure the relative importance solvent and insolvent firms attach to the extracted financial ratio dimensions using 3-way MDS enabling us to examine differences between them. Using IBM SPSS 20, we conducted the 3-way MDS in four stages. First, we calculated Euclidean distance-based proximities among the 28 ratios. Second, to decide the number of dimensions to retain in the final solution, we adopted a strategy followed by similar studies (Neophytou and Molinero, 2004b, Chipulu et al., 2013) of independently establishing the dimensionality of the data a priori of the final three-way MDS. We iteratively submitted the proximity matrix for all sampled firms (solvent and insolvent) to MDS analysis using the Proxscal algorithm, each time extracting a different number of dimensions. We then used a scree plot of the normalised stress (a "badness-of-fit" measure) for successive numbers of dimensions to judge optimal dimensionality. Third, we extracted the individual proximity matrices of the 28 financial ratios for solvent and insolvent firms; and entered them as inputs into three-way MDS model using the Prefscal algorithm (Busing et al., 2005), specifying that the number of dimensions decided in the second stage of the analysis be retained. The Prefscal algorithm began by extracting a common (to both types of firms) multidimensional space. Individual spaces for each type of firm were then extracted by rescaling (shrinking or extending) the common space along the dimensions based on the weight that each type of firm places on that dimension. We then used the re-scaling weights to examine the relative importance each type of firm (i.e. solvent or insolvent) attaches to each dimension. Finally, to support the interpretation of the MDS dimensions, we supplemented the MDS results by clusters of ratios obtained from an independently conducted hierarchical cluster analysis (HCA) (Gupta and Huefner, 1972, Neophytou and Molinero, 2004b). Based on Euclidean distance proximities among them, we clustered the 28 ratios using Ward's method, which we judged the most appropriate for this 
purpose because it leads to compact clusters by minimising cluster variance (Punj and Stewart, 1983)

The rationale behind our choice of 3-way MDS is that it reveals, as much as possible, the hidden structure in the data based on similarities among the financial ratios. This addresses $R Q 2$ and so other data reduction techniques such as PCA could have been applied instead. Recent examples of the application of PCA with financial ratios can be found in Min and Lee (2005) and Canbas et al. (2005). We chose 3-way MDS over other techniques for two reasons. First, by examining the weights that solvent and insolvent firms attach to the dimensions, we are able to address the third research question directly. This would have not been possible with a technique such as PCA without secondary analysis of the results. Second, it is thought that the dimensions arising from 3-way MDS are easier to interpret (than, say, PCA components) because the re-scaling of the common space using individual weights is strictly dimensional (Arabie et al., 1987).

\section{Results}

\section{Logit Model Insolvency Prediction}

Table 4 Training data predictive performance of most frequent best-six ratio sets

\begin{tabular}{|l|l|l|l|l|l|}
\hline Set & Best-Six Ratios Set & $\mathrm{N}$ & $\%$ & AUC & Weighted AUC \\
\hline 1 & EBITCE, EBITTL, TLTA, CFFOTA, CFFOCL, TDCFFO & 69 & 6.9 & 0.989 & 68.2 \\
\hline 2 & EBITCE, EBITS, EBITTL, SETL, TLTA, TDCFFO & 23 & 2.3 & 0.9651 & 22.2 \\
\hline 3 & EBITCE, EBITTL, TLTA, CFFOTA, CFFOCL, CFFOTL & 23 & 2.3 & 0.9981 & 23 \\
\hline 4 & EBITTL, TLNW, WCTA, CFFOTA, CFFOCL, CFFOTL & 21 & 2.1 & 0.9917 & 20.8 \\
\hline 5 & EBITCE, EBITS, SETA, TLTA, TDCFFO, MVOETD & 19 & 1.9 & 0.9871 & 18.8 \\
\hline 6 & EBITCE, EBITTL, TLTA, CFFOTA, CFFOTL, TDCFFO & 17 & 1.7 & 0.9761 & 16.6 \\
\hline 7 & EBITTL, TLTA, TLNW, CR, CFFOTA, CFFOTL & 13 & 1.3 & 0.9752 & 12.7 \\
\hline 8 & EBITTL, TLTA, TLNW, CFFOTA, CFFOTL, TDCFFO & 12 & 1.2 & 0.9752 & 11.7 \\
\hline
\end{tabular}

The 1000 bootstrap replicates produced 497 unique sets of best-six predictors, indicating the uncertainty surrounding the predictive ability of the 28 ratios. Although most sets appeared only once, there were eight sets exceeding 1\% frequency. As shown in table 4 , the eight sets comprised 14 different ratios. Set 1 containing EBITCE, 
EBITTL, TLTA, CFFOTA, CFFOCL and TDCFFO was the most frequent, appearing thrice as much as the next most frequent set; and it performed best on frequencyweighted AUC of the ROC curve for the training data set. Inspection of table 4 suggests that beyond set 1, EBITCE, EBITTL, TLTA, CFFOTA, CFFOCL and TDCFFO also frequently appear in other best-six sets. Each of the six ratios is present in at least four of the other seven most frequent sets. There is hence a common pattern across the eight sets: except for sets 5 and 7, which respectively contain a liquidity and market ratio, the eight sets comprise ratios from the profitability, leverage and cash flow categories; however, there is no activity ratio in any of the eight sets. Thus, while the exact combination of best-six ratios is uncertain, it is likely profitability, leverage and cash flow ratios will offer more predictive value than liquidity, market, and, in particular, activity ratios.

The final training model fit statistics with EBITCE, EBITTL, TLTA, CFFOTA, CFFOCL and TDCFFO as predictors were good [Likelihood Ratio Chi-squared = 74.4, p-value $<0.0001$; Pseudo R-square value (Nagelkerke) $=0.90$ ], indicating that these six variables provide some explanation for firm insolvency. Table 5 shows the parameter estimates. Except for EBITCE and TDCFFO, the estimated coefficients of the ratios are significant at the .05 p-value level. The results suggest that higher levels of TLTA and CFFOCL will increase the likelihood of insolvency, whereas EBITTL, CFFOTA and TDCFFO will reduce it. Of these, CFFOTA, with the largest coefficient, is likely to have the greatest effect.

Table 5 Parameter estimates of predictors for insolvency

\begin{tabular}{|c|l|c|c|c|c|}
\hline Parameter & \multicolumn{1}{|c|}{ Description of Ratio } & Estimate & $\begin{array}{c}\text { Standard } \\
\text { Error }\end{array}$ & $\begin{array}{c}\text { Wald } \\
\text { Chi- } \\
\text { Square }\end{array}$ & $\begin{array}{c}\text { Pr > Chi } \\
\text { Sq }\end{array}$ \\
\hline Intercept & & -2.5 & 1.5 & 2.8 & 0.096 \\
\hline EBITCE & Profitability - Return On Capital Employed & -9.6 & 5 & 3.7 & 0.054 \\
\hline EBITTL & Profitability - Earing To Total Liabilities & -8 & 3.4 & 5.6 & 0.018 \\
\hline TLTA & Leverage - Total Liabilities To Total Assets & 1.8 & 0.9 & 4.2 & 0.041 \\
\hline CFFOTA & Cash flow - Cash Flow On Assets & -78.2 & 35.6 & 4.8 & 0.028 \\
\hline CFFOCL & Cash flow - Cash Flow on Current Liabilities & 11.5 & 5.3 & 4.7 & 0.03 \\
\hline TDCFFO & Cash flow - Total Debt To Cash Flow Ratio & -0.2 & 0.1 & 1.7 & 0.187 \\
\hline
\end{tabular}


To validate the model, we then re-estimated the logistic regression with the four significant ratios, namely EBITTL, TLTA, CFFOTA and CFFOCL - as predictors and used the estimated parameters of the four predictors to score the test data set. The full results of this predictive logistic model are shown in Appendix II. The AUC of the ROC curve based on scoring the test data set was 0.97. This AUC value is very close to 1 (= perfect classification) and substantially greater than 0.5 (= random classifier). Thus, we can conclude that these four ratios can be used to predict insolvency of GCC firms before it occurs and that the cash flow ratios CFFOTA and CFFOCL may be useful predictors of insolvency in the GCC. The ex-ante, validation test shows that the model has $84.8 \%, 95.6 \%$ and $73.9 \%$ overall, type I and II classification levels of respectively.

The Probit model results are shown in Appendix III. They closely replicate the Logit results: the estimated parameters of the four predictors are very similar, and the two models have identical classification levels on the test data.

\section{MDS Dimensionality}

Figure 1 shows the scree plot from the Proxscal MDS models. There is no clear 'elbow' to indicate optimal dimensionality; however, this is not unusual in MDS. Experience shows that higher dimensions are increasingly harder to interpret as they account for more residual than common variance; and, typically, researchers trade-off the higher variance accounted for which comes with higher dimensionality in favour of lower dimensionality and higher interpretability (Neophytou and Molinero, 2004a, Chipulu et al., 2013). According to Kruskal and Wish (1978), an MDS configuration represents a 'good' fit when stress is 0.05 and is 'very good' at 0.01 . 


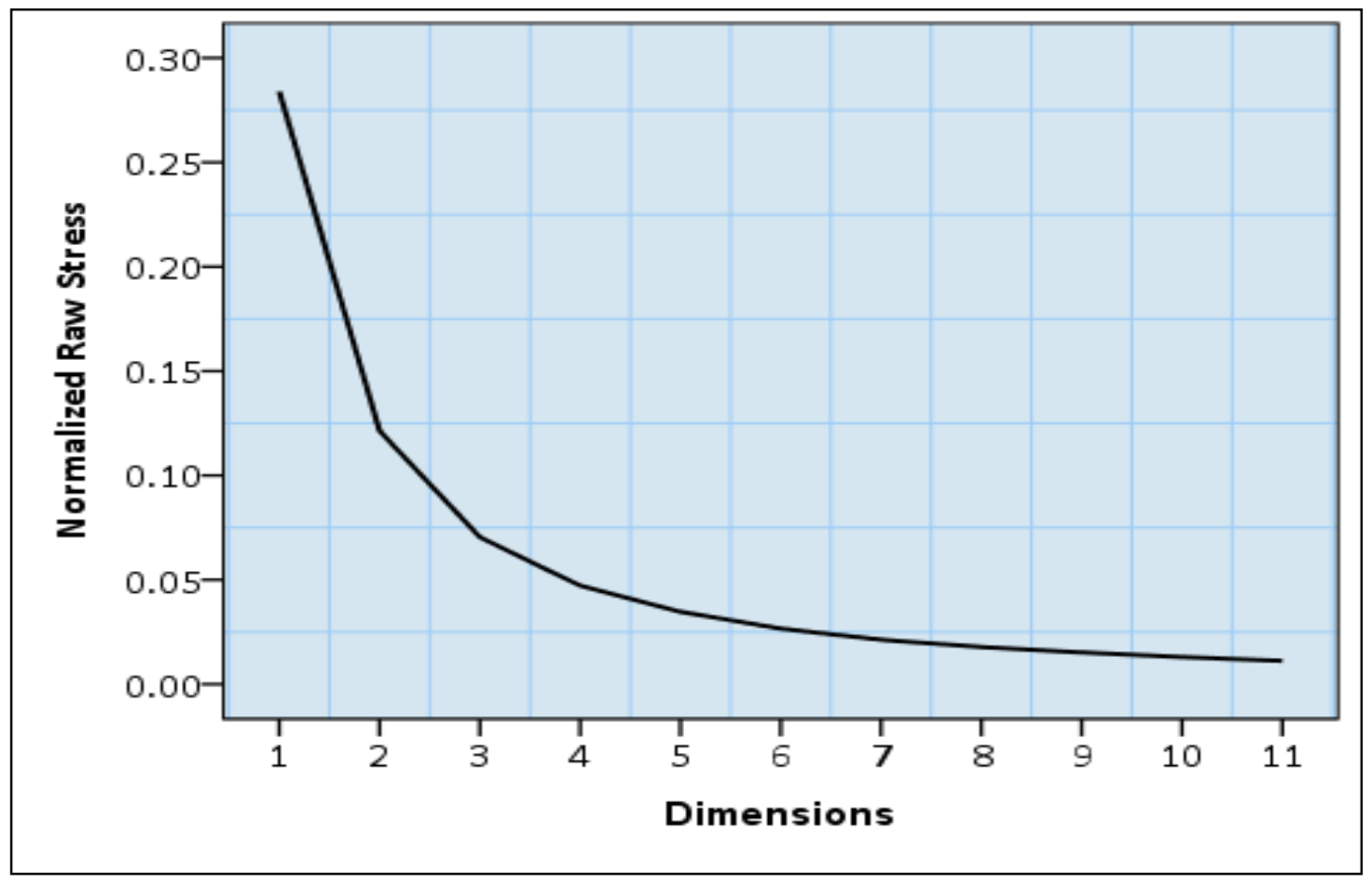

Fig.1 MDS Proxscal Models’ Goodness-of-fit

In figure 1, model fit clearly improves between one and four dimensions when stress drops to 0.05 (a 'good' fit). After four, incremental improvements diminish and stress does not reach 0.01 even at 11 dimensions. This implies that at least 11 dimensions are required to obtain a 'very-good': yet each additional dimension after four improves fit only marginally. Therefore we decided to extract four dimensions as this represents the lowest dimension (and so highest interpretability) configuration that reaches a 'good' fit.

\section{MDS Model Fit and Coordinates of Ratios}

The final 3-way MDS model, retaining four dimensions, was a good fit for the data with a normalised stress value of 0.03 , and accounted for $87 \%$ of the variance. Degenerate indices (DeSarbo's inter-mixedness $=0.22$; Shepard's rough non-degeneracy $=0.76$ ) were such that we can conclude the model is unlikely to be degenerate. Table 6 shows the dimensional coordinates of the financial ratios. The absolute value of a ratio's coordinate on each dimension is indicative of its level of association with that dimension. Ratios with very high absolute values can be used to interpret each 
dimension as they are the most representative of that dimension (Chipulu et al., 2013). In table 6, we have highlighted the ratios with large (absolute) value coordinates that we have used for this purpose.

Table 6 MDS dimensional coordinates of financial ratios

\begin{tabular}{|c|c|c|c|c|c|}
\hline $\begin{array}{l}\text { Financial } \\
\text { Ratio }\end{array}$ & Description & Dim_1 & Dim_2 & Dim_3 & Dim_4 \\
\hline CFFOS & Cash Flow - Cash flow on Sales & .750 & -.268 & 1.049 & .076 \\
\hline TDCFFO & Cash Flow - Total Debt To Cash Flow Ratio & .706 & -1.171 & .618 & -.057 \\
\hline$G P M$ & Profitability - Gross Profit Margin & .671 & -.450 & 1.044 & .212 \\
\hline TDS & Activity - Debt Ratio & .602 & -1.058 & -1.020 & .144 \\
\hline$S W C$ & Activity - Working Capital Turnover & .550 & -.680 & .595 & .489 \\
\hline$I T$ & Activity - Inventory Turnover & .344 & -.722 & .530 & 1.164 \\
\hline SETA & Leverage - Equity To Total Assets & .158 & .427 & .686 & .536 \\
\hline EBITS & Profitability - EBIT Margin & .080 & .086 & -.089 & 2.213 \\
\hline MVOETD & Market - Market Value To Debt & -.462 & -.577 & .160 & 1.835 \\
\hline SETD & Leverage - Equity To Debt & -.676 & -.824 & -.327 & 1.899 \\
\hline$T L N W$ & Leverage - Total Liabilities To Net Worth & -.740 & -1.000 & -1.156 & .934 \\
\hline SFA & Activity - Fixed Asset Turnover & -.776 & -.832 & -.794 & 1.619 \\
\hline SETL & Leverage - Equity To Total Liabilities & -.973 & -1.044 & -1.126 & .647 \\
\hline MVOESE & Market - Market Value To Equity & -1.002 & -1.055 & -1.261 & .374 \\
\hline EBITSEQ & Profitability - Return On Equity & -1.051 & .883 & .392 & -.096 \\
\hline$S C A$ & Activity - Sales To Current Assets & -1.146 & -1.183 & -1.299 & -.465 \\
\hline CFFONW & Cash Flow - Cash Flow on Net Worth & -1.187 & -1.209 & -1.336 & -.903 \\
\hline$C R$ & Liquidity - Current Ratio & -1.203 & -1.182 & -1.276 & -.425 \\
\hline$Q R$ & Liquidity - Quick Ratio & -1.238 & -1.222 & -1.304 & -.700 \\
\hline TLTA & Leverage - Total Liabilities To Total Assets & -1.246 & -1.219 & -1.339 & -.909 \\
\hline$A T$ & Activity - Total Asset Turnover & -1.251 & -1.216 & -1.351 & -.857 \\
\hline RETA & $\begin{array}{l}\text { Leverage - Retained Earnings To Total } \\
\text { Assets }\end{array}$ & -1.260 & -1.202 & -1.303 & -.917 \\
\hline EBITTL & Profitability - Earning To Total Liabilities & -1.262 & 1.265 & .006 & -.334 \\
\hline EBITCE & Profitability - Return On Capital Employed & -1.267 & 1.232 & .069 & -.281 \\
\hline WCTA & Liquidity - Working Capital To Total Assets & -1.276 & -1.205 & -1.323 & -.942 \\
\hline CFFOCL & Cash Flow - Cash Flow on Current Liabilities & -1.276 & -1.230 & -1.327 & -.924 \\
\hline CFFOTL & Cash Flow - Cash Flow on Total Liabilities & -1.291 & -1.225 & -1.334 & -.969 \\
\hline CFFOTA & Cash Flow - Cash Flow On Assets & -1.294 & -1.207 & -1.315 & -.982 \\
\hline
\end{tabular}




\section{HCA Clusters of Ratios}

It is not possible to visualise the positions of the ratios in a four-dimensional (4D) space, so we created two-dimensional (2D) projections of the MDS configuration. However, as the true configuration is four-dimensional, distances between ratios in the 2D space can be misleading: two proximate ratios that therefore seem similar in, for example, dimensions 1 and 2, could actually be far apart in dimensions 3 or 4 , and not as similar as they appear. It is important then to indicate on the 2D maps overall distances among ratios. One approach to this problem is to superimpose the 2D maps with a layer of the clusters obtained from HCA (Neophytou and Molinero, 2004b).

Table 7 HCA Cluster Membership

\begin{tabular}{|c|c|c|c|}
\hline \multicolumn{2}{|l|}{ Cluster 1} & \multicolumn{2}{|l|}{ Cluster 2} \\
\hline$\overline{S F A}$ & Activity - Fixed Asset Turnover & EBITTL & Profitability - Earning To Total Liabilities \\
\hline SCA & Activity - Sales To Current Assets & EBITS & Profitability - EBIT Margin \\
\hline$A T$ & Activity - Total Asset Turnover & EBITCE & Profitability - Return On Capital Employed \\
\hline CFFOTA & Cash flow - Cash Flow On Assets & EBITSEQ & Profitability - Return On Equity \\
\hline CFFOCL & Cash flow - Cash Flow on Current Liabilities & & \\
\hline CFFONW & Cash flow - Cash Flow on Net Worth & \multicolumn{2}{|l|}{ Cluster 3} \\
\hline CFFOTL & Cash flow - Cash Flow on Total Liabilities & TDS & Activity - Debt Ratio \\
\hline SETD & Leverage - Equity To Debt & IT & Activity - Inventory Turnover \\
\hline SETL & Leverage - Equity To Total Liabilities & SWC & Activity - Working Capital Turnover \\
\hline RETA & $\begin{array}{l}\text { Leverage - Retained Earnings To Total } \\
\text { Assets }\end{array}$ & SETA & Leverage - Equity To Total Assets \\
\hline TLNW & Leverage - Total Liabilities To Net Worth & \multicolumn{2}{|l|}{ Cluster 4} \\
\hline TLTA & Leverage - Total Liabilities To Total Assets & $G P M$ & Profitability - Gross Profit Margin \\
\hline$C R$ & Liquidity - Current Ratio & \multicolumn{2}{|l|}{ Cluster 5} \\
\hline$Q R$ & Liquidity - Quick Ratio & TDCFFO & Cash flow - Total Debt To Cash Flow Ratio \\
\hline$\overline{W C T A}$ & Liquidity - Working Capital To Total Assets & \multicolumn{2}{|l|}{ Cluster 6} \\
\hline MVOETD & Market - Market Value To Debt & CFFOS & Cash flow - Cash flow on Sales \\
\hline MVOESE & Market - Market Value To Equity & & \\
\hline
\end{tabular}

There were five stages in the HCA agglomeration schedule. There was a sixcluster solution at stage one comprising three multiple-ratio clusters; and three unattached ratios: GPM, TDCFFO and CFFOS. There were four clusters at stage two: the three multiple-ratio clusters merged into one large cluster; while GPM, TDCFFO and CFFOS remained unattached. GPM joined the large cluster at stage three, TDCFFO at stage four and CFFOS at stage five. Stage one thus represents the greatest cluster separation and so we decided to extract the six clusters at this level. Cluster membership is summarised in table 7 . The schedule suggests the three larger clusters 
have more similarities among them than with GPM, TDCFFO or CFFOS. GPM, TDCFFO and CFFOS, particularly, are dissimilar to the other 25 ratios. They could be key indicators in that they carry unique information not shared by other ratios. We interpreted the three larger clusters as follows:

Cluster 1, the largest with 17 ratios, contains all the liquidity ratios, all but one of the leverage ratios and both market ratios; but none of the profitability ratios. This combination of ratios led us to interpret cluster 1 as an indicator of non-profitabilitybased market valuation of financial stability; and that the cash flow and activity ratios that are also in cluster 1 are closely related to market valuation of financial stability.

Cluster 2 contains only profitability ratios, which can be used to determine a company's ability to produce a return on investment. We believe this cluster represents profitability.

All except one of the ratios in cluster 3 are indicative of sales activity (IT, SWC, TDS). We believe this cluster represents sales activities, which is related to SETA (equity to total assets), the fourth ratio in the cluster.

\section{Interpretation of ratio dimensions}

Using the relative positions of the six clusters on the 2D MDS maps and the signs and sizes of dimensional coordinates of the ratios (table 6), we interpreted the four dimensions as follows

\section{Dimension 1: 'Non-strategic sales activities'}

Figure 2 shows the projection of the MDS structure in dimensions 1 and 2. MDS dimensions are extracted hierarchically based on variance accounted for, with the first dimension accounting for the most and the amount decreasing with each additional dimension. As such, dimensions 1 and 2 should capture a substantial amount of the pattern of similarities among ratios, closely mirroring the cluster patterns. It can be seen in figure 2 that this is the case. All six clusters occupy clear and distinct positions on the map. Cluster 3, an indicator of sales activities, is entirely on the right-hand side of 
dimension 1; as are the three unattached ratios CFFOS, GPM and TDCFFO, which along with TDS - have the highest positive-valued coordinates on dimension 1. CFFOS measures cash generated from sales; GPM measures sales over costs. This suggests a need to maintain high sales activities to generate cash to cover financial obligations, where these obligations are reflected by the proximity of TDCFFO and TDS. In this case, however, the focus on sales activities is at the expense of profitability and financial stability as inspection of the left-hand side shows. The entire market valuation of financial stability cluster and most of the profitability cluster are on the negative side of dimension 1, indicating decreasing levels of both the markets' valuation of financial stability and profitability. This suggests a lack of long-term, strategic planning which is needed to ensure that sales activities not only generate profits but are conducted within a stable financial environment, engendering market value. Thus, we interpreted dimension 1 as an indicator of operational, non-strategic focus on sales activities.

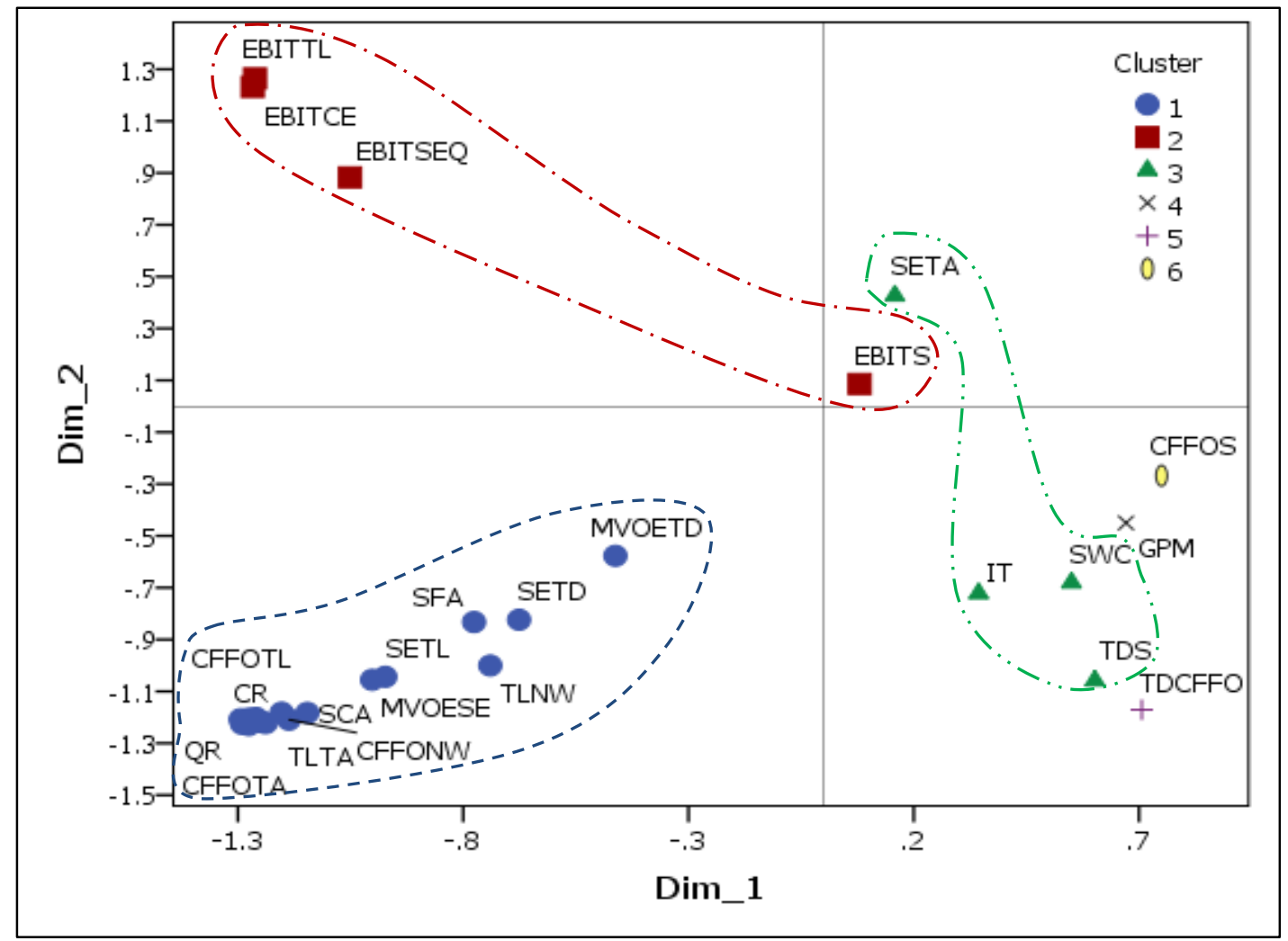

Fig. 2 MDS Dimensions 1 versus 2 and HCA Cluster 


\section{Dimension 2: 'Profitability and financial stability balance'}

Clusters 1 and 2 occupy different halves of dimension 2; whereas cluster 3 overlaps the two halves. The three ratios (EBITTL, EBITCE and EBITSEQ) with the highest positive valued coordinates on dimension 2 are all in cluster 2 (profitability). In contrast, cash flow over liabilities ratios (CFFOCL, CFFOTL) and the quick ratio (liquidity) and TLTA (leverage) have high negative coordinates on dimension 2. Together, these ratios indicate a firm's ability to handle both its short- and long-term liabilities, i.e. financial stability. We interpreted dimension 2 to represent a balance between profitability and financial stability.

Dimension 3: 'Sales activities against capital conversion'

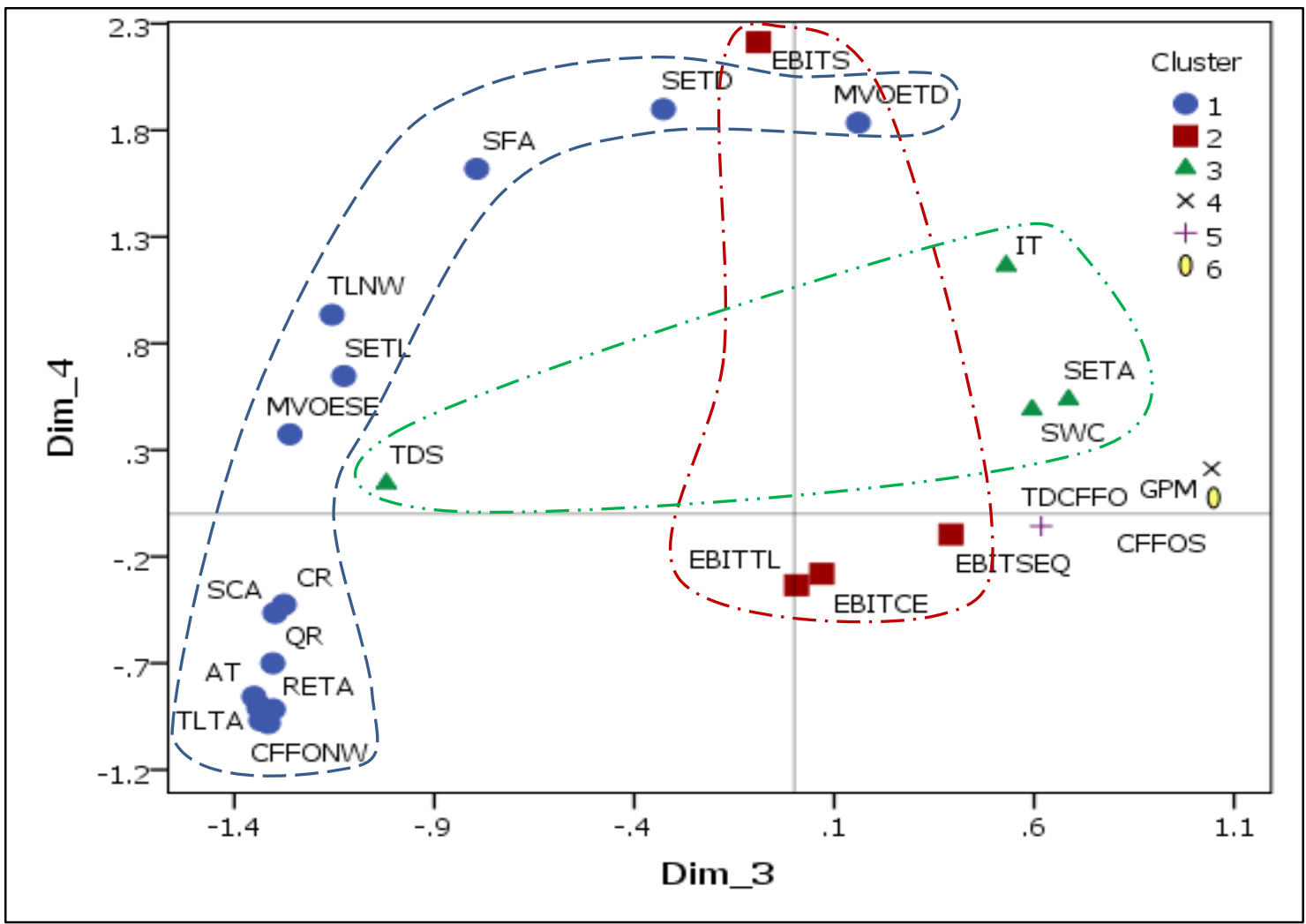

Fig. 3 MDS Dimensions 3 versus 4 and HCA Clusters

Figure 3 shows the projection of the MDS structure in dimensions 3 and 4. Unlike the dimensions 1 and 2 space, in this projection the clusters are not as compact and they 
overlap each other, i.e. they do not occupy clear and distinct areas of the map. These cluster transformations offer additional support for extracting a four-dimensional structure; they indicate that dimensions 3 and 4 offer extra insight (to 1 and 2) analogous to how regions in a country that are very similar in most aspects (for example geographical location, weather, population, etc.) may appear quite different when viewed in terms of urbanity and social deprivation.

On first inspection, based on the relative positions of the variables, dimension 3 appears very similar to dimension 1 . Like 1, the ratios with high positive valued coordinates on dimension 3 - namely CFFOS, GPM, DCFFO - and most of the ratios in cluster 3 appear to indicate higher sales activities. Closer inspection, however, suggests noticeable differences. Whereas all the profitability ratios have large negative coordinate values on dimension 1 , on 3 all profitability ratios have very small values, near zero. Dimension 3 does not appear to be strongly related to profitability. Similarly, it does not appear to be as strongly related to the market value and leverage ratios. Overall, unlike 1 , the ratios on the negative side of dimension 3 do not give a clear indication of decreasing profitability and financial stability and, consequently, marketvalue. Rather, the two ratios with the highest negative valued coordinates, namely $A T$ (total asset turnover) and TLTA (total liabilities to total assets); are, respectively, indicative of the efficiency in using own assets to generate sales and the effectiveness of using creditors' funds to acquire assets (Bragg, 2002, Megginson and Smart, 2005). This suggests the negative side of dimension 3 could be a reflection of return on capital. Thus, we interpreted dimension 3 as a balance between sales activities against capital conversion.

\section{Dimension 4: 'Market value against cash generation' effectiveness}

Dimension 4 transforms clusters 1 and 2 so that EBITS, a profitability measure from cluster 2, has a high positive-valued coordinate; and is located near cluster 1 ratios: MVOETD (market value to debt), SETD (equity to total debt), and SFA (fixed asset turnover). This combination of ratios indicates increasing efficiency in converting assets and debts into earnings and market value. In contrast, the ratios with the highest 
negative-valued coordinates are from the cash flow group (CFFOCL, CFFOTL, CFFOTA), indicating difficulties in generating cash from operations or inefficiencies in credit and cash collection. Therefore, we interpreted dimension 4 to indicate a balance between creating market value against cash generation.

\section{Relative Importance of Ratio Dimensions}

Table 8 shows the importance that 'solvent' or 'insolvent' firms ascribe to the four the four dimensions, how specific they are in attaching importance, and the importance (relative to other dimensions) of each dimension based on the amount of variance it accounts for. For each firm category, the dimensional weights can be used to compare the importance that firm category places on that dimension relative to the other three dimensions. For each dimension, dimension weights can be used to compare the importance that 'insolvent' firms attach to it relative to 'solvent' firms. The 'specificity' indicates the extent to which a source attaches weight to a specific dimension while overlooking others: values can range from zero for a source which regards all dimensions as equally important to one for a source which regards only one of the dimensions as important. An intuitive interpretation of specificity is that it captures the trade-off a source makes between focus on one, some or all of the dimensions: as emphasis on one or a few dimensions increases, lack of emphasis on the others may ensue. It can be seen thus that insolvent firms are very specific. They place a very large amount of weight on dimension 1; little or no weight on dimensions 2 and 3 , and some weight on dimension four. In contrast, solvent firms are only moderately specific: instead of dimension 1 which appears unimportant to them, they place the most weight on dimension 2; and less, but still comparatively, much higher weights than insolvent firms on both dimensions 3 and 4 . The importance values indicate that dimension 1 represents $40 \%$ of the overall variance extracted by the MDS structure. Since solvent firms appear to disregard this dimension, dimension 1 almost exclusively captures all the structural variations in ratios among insolvent firms, whereas the other three dimensions are more representative of solvent firms.

Table 8 Dimensional salience by firm failure category 


\begin{tabular}{|c|c|c|c|c|c|}
\hline \multirow{2}{*}{ Type of the Firm } & \multicolumn{4}{|c|}{ Dimension } & \multirow{2}{*}{ Specificity } \\
\hline & Dim_1 & Dim_2 & Dim_3 & Dim_4 & \\
\hline Insolvent Firms & 540.1 & .0 & 8.2 & 104.9 & .831 \\
\hline Solvent Firms & .1 & 444.6 & 350.6 & 204.5 & .524 \\
\hline Importance & .4 & .3 & .2 & .1 & \\
\hline
\end{tabular}

5 Discussion

Above, after reviewing the literature, we concluded that, overall, no set of financial ratios is found to consistently predict firm failure. Rather, the set of ratios found significant varies by study (Altman and Narayanan, 1997). The results we have obtained from logistic regression modelling aimed at addressing our first research question (RQ1) - What are the significant predictors of insolvency in the GCC region; and do they include cash flow-based ratios? - mirror this synopsis of the literature. In our examination of six predictor subsets using 1000 bootstrap replications of the original training data set, we found that the 'best sets' varied considerably. Based on the premise that sets that appear with higher frequency are likely to be more robust, we examined the most frequent 'best sets'. We found that the sets were only marginally different in predictive performance, i.e. no set was unequivocally dominant. Given this uncertainty and lack of discriminability among sets, it is difficult to claim that one single set of ratios will consistently achieve high prediction performance, data changes notwithstanding. What our logistic regression appears to have uncovered is a general pattern: in the GCC context, ratios from the profitability, leverage and cash-flow groups are likely to contain insolvency predictive information.

Of the six predictors in the final Logit model, four, namely EBITTL, TLTA, CFFOTA, and CFFOCL, were significant. When we re-ran the prediction model using Probit regression, we were able to replicate the Logit results, confirming that the predictive capacity of these four ratios is not a mere artefact of the logistic model. Rather, it appears be a characteristic of the four ratios, which is independent of the predictive technique used. To assess how unique the significance of these four ratios is, we took a sample of 28 failure prediction studies for comparison. The 28 studies were selected to ensure representation of research over time (Beaver, 1966 to the present day), across locations and by classification techniques. Details of the 28 studies, 
including the significanc of the 28 ratios under consideration, are shown in Appendix IV. A count of number of occurrences of each ratio in the 28 studies suggests that the type of ratio most frequently reported significant is liquidity, having appeared first in the seminal studies of Beaver (1966) and Altman (1968). Our not finding any liquidity ratio to be significant is thus a contrast. This finding is not unusual, though: previous studies in the GCC such as Aldeehani (1995) and Basheikh (2012) did not find any liquidity ratio to be significant either. Perhaps liquidity ratios have lower predictive capacity in the GCC than elsewhere. We also did not find any activity or market ratio to be significant; but unlike liquidity, this type of ratio is rarely reported as significant in the literature, indicating low predictive capacity generally.

Based on theory (Gilbert et al., 1990) and empirical results elsewhere (e.g. Blum, 1974, Smith and Liou, 1979, Mensah, 1984, Aziz et al., 1988, Aziz and Lawson, 1989, Gilbert et al., 1990, Charitou et al., 2004) we posited that cash flow ratios should be of predictive value in the GCC context. The significance of CFFOTA and CFFOCL provides support for this postulate. Furthermore, CFFOTA, which has been reported significant in several other studies in different contexts (Shumway, 2001, Bose, 2006, Ravisankar et al., 2010) had by far the largest estimated effect. CFFOCL, also reported significant by Gilbert et al. (1990), had the second largest effect. These large cash flow ratio effects tend to support the argument that cash flow-based ratios may contain more predictive information than most other ratios (Gombola and Ketz, 1983). Consequently, the disregard of cash flow ratios seems to us a clear weakness in previous GCC insolvency research: cash flow-based ratios should be included when insolvency prediction models are constructed in the GCC.

The significance of EBITTL suggests that profitability is as good a predictor of insolvency in the GCC as it is in other contexts: EBITTL was also reported significant by Charitou et al. (2004) in the UK and Gloubos and Grammatikos (1988) in Greece. In the GCC, Basheikh (2012) found EBITSEQ, another profitability ratio, to be significant. Similarly, though it has the smallest estimated effect in our Logit model, TLTA is very often reported significant in the literature (e.g. Ohlson, 1980, Altman and Lavallee, 1981, Zmijewski, 1984, Zavgren, 1985, Gloubos and Grammatikos, 1988, Shumway, 
2001, Charitou et al., 2004). We can hence conclude that leverage is as good a predictor of insolvency in the GCC as it is elsewhere.

The Logit model performed very well in the forecast validation test. As shown in table 9, the model accuracy levels are impressive even when compared to in-sample or ex-post validation results: It is well known that in-sample validation tends to overestimate model performance (e.g. Hawkins, 2004); and it has been suggested that impressive ex-post classification rates can drop by $10 \%$ or more on ex-ante tests (Platt and Platt, 1990). Type I errors are considered much more costly than type II (e.g. Altman et al., 1977). It is good then that, like those of Altman (1968) and Charitou et al. (2004), the Logit model is better at classifying insolvency than solvency. We should also note that we partitioned the data such that the training data were for the period before and up to the onset of the 2008 financial crisis (2004-2009), whereas the test set data were post-crisis (2010-2011). The 2008 crisis is thought to have significantly affected the GCC economies including triggering the Dubai debt crisis (Khamis and Senhadji, 2010, Onour, 2010). Thus, the level of accuracy of the logistic model in correctly classifying firms after the 2008 financial crisis is notable given the potential confounding influence of the crisis.

Table 9 Comparative accuracy of a sample of insolvency studies

\begin{tabular}{|c|c|c|c|c|}
\hline \multirow[t]{2}{*}{ Study Details } & \multirow[t]{2}{*}{ Location of Study } & \multicolumn{3}{|c|}{ Accuracy (\%) } \\
\hline & & Overall & Type I & Type II \\
\hline Current Study*** & GCC & 84.8 & 95.6 & 73.9 \\
\hline Peel et al. (1986)*** & United Kingdom & 91.7 & 83.4 & 100 \\
\hline Charitou et al. (2004)*** & United Kingdom & 80.95 & 85.71 & 76.19 \\
\hline $\begin{array}{l}\text { Gloubos and Grammatikos } \\
\text { (1988)*** }\end{array}$ & Greece & 77.1 & 66.7 & 87.5 \\
\hline Ta and Seah (1988)** & Singapore & 86.2 & 75 & 90.5 \\
\hline Keasey and McGuinness (1990)*** & United Kingdom & 63 & 56 & 70 \\
\hline Altman (1968)** & United States & 85.5 & 96 & 79 \\
\hline Zavgren (1985)* & United States & 82 & 89 & 76 \\
\hline Basheikh (2012)* & Saudi Arabia & 83.8 & 83.3 & 84.2 \\
\hline $\begin{array}{l}* * * \text { out-sample, ex-ante } \\
* * \text { out-sample, ex-post } \\
* \text { in-sample }\end{array}$ & & & & \\
\hline
\end{tabular}


Our second and third research questions were, respectively, What are the key financial ratio dimensions in the GCC? and Relatively, what are the differences between solvent and insolvent firms in the salience they attach to financial ratio dimensions? Rather than prediction, these two questions were aimed at generating insight as to why some firms might be more susceptible to insolvency than others. Using 3-way MDS supplemented by hierarchical cluster analysis, we found that, based on proximities, the 28 financial ratios under study can be reduced to four main dimensions. In order of decreasing importance (measured by the amount of the variance each dimension accounts for), the four dimensions were (i) 'Non-strategic sales activities', (ii) 'Profitability and financial stability balance', (iii) 'Sales activities against capital conversion', and (iv) 'Market value against cash generation'. By examining the amount of weight each group puts on these four dimensions, we uncovered marked differences between solvent and insolvent firms. Insolvent firms place most weight on dimension 1 ('Non-strategic sales activities') and very little on the other three. Solvent firms appear, by contrast, to disregard dimension 1 and place much more weight not only on dimension 2 ('Profitability and financial stability balance') but also on dimensions 3 ('Sales activities against capital conversion') and 4 ('Market value against cash generation'). This suggests that insolvent firms have a one-dimensional focus on 'non-strategic sales activities' (dimension 1), encapsulated in their high specificity value. Based on the relative positions of ratios in our MDS maps, we believe that the near-singular focus on 'non-strategic sales activities' by insolvent firms is likely a reactive, pragmatic stance dictated by a need to meet financial obligations. This inference is supported by the Logit results, which indicate that the level of cash relative to liabilities (CFFOCL) can significantly affect susceptibility to insolvency. Taking the multidimensional focus of solvent firms as exemplar, the MDS results imply, however, that focusing so exclusively on 'non-strategic sales activities'; while paying little regard to other dimensions, increases the risk of insolvency: it could harm profitability, put stability at risk and reduce market value. In other words, the implication for managers of firms in financial distress is to shift focus away from 'non-strategic sales activities' and much more on to 'profitability and financial stability balance' and 'sales activities 
against capital conversion', as solvent firms do. Likewise, managers of healthy firms should periodically evaluate strategy and, whenever signs of over-valuing 'nonstrategic sales activities' are spotted, refocus on 'profitability and financial stability balance' and 'sales activities against capital conversion'.

Overall, we believe our results indicate some parallels as well as differences between insolvency in the GCC and in other regions. The Logit results confirm that financial ratios in general and cash flow ratios in particular can be used to detect firm's distress in the GCC as effectively as elsewhere. On the other hand, contrary to previous studies, the Logit results also indicate that liquidity ratios are not very good predictors of insolvency in the GCC. We note also that, in our MDS model, market value ratios are most strongly associated with the fourth dimension, which, based on amount of variance accounted for, is the least important of the four dimensions extracted. This may be a result of inefficiency in GCC markets (Arouri et al., 2011, Al-Ajmi and Kim, 2012); one of the key differences between the GCC and other major trading blocs such as NAFTA that we mentioned earlier. The implication for stakeholders, particularly investors, is that market values of GCC firms may not be as strongly associated with the financial health of the firms as they are in more efficient markets.

\section{Conclusion}

This study makes several contributions to the literature on corporate insolvency. To date, there has been relatively little research on insolvency in the GCC; and many of the existing studies have relied on Altman's model. This study breaks new ground by examining insolvency across the whole GCC, using multiple methodologies: a Logit model with a Probit model for extra validation, and a 3-way MDS model supplemented by Cluster Analysis. Thus, it extends the geographical coverage and methodological scope of corporate insolvency studies in the GCC. Beyond the GCC, as one of only a few studies to have conducted ex-ante validation, this study extends the pool of countries where validated insolvency classification models have been found. This is a worthwhile contribution in itself because we now have documented evidence of which ratios are likely to be good predictors of insolvency in, for example, the UAE. Arguably, 
however, the greatest contribution of this study is that, using MDS, it reveals the characteristic differences between solvent and insolvent firms, which we believe can aid managers of both types of firms take action to reduce susceptibility to insolvency.

We envisage a number of ways in which this research can be improved. Like other 'developing' (i.e. middle- and lower-income) regions, not only is the number of publicly listed companies in the GCC small but there is also very little data on insolvent firms because the stock markets are relatively nascent. Therefore, it will be valuable to re-model insolvency in the GCC as more data on insolvent firms emerge. Second, the GCC context has unique characteristics. This begs the question: to what extent are the structural differences between insolvent and solvent firms indicated by our MDS results idiosyncratic to the region? To examine this question, our forthcoming study will investigate whether or not the differences we have uncovered are generalisable, i.e. do similar structural differences exist between solvent and insolvent firms in other contexts such as the United Kingdom? 


\section{References}

Abudelrahman N (2004) An analytical study on some models of predicting financial failure applied on Saudi Arabia corporate companies. King Abdulaziz University, Jeddah.

Al-Ajmi J and Kim J (2012) Are Gulf stock markets efficient? Evidence from new multiple variance ratio tests. Applied Economics 44, 1737-47.

Al-Khazali OM, Ding DK, and Pyun CS (2007) A new variance ratio test of random walk in emerging markets: a revisit. Financial Review 42, 303-17.

Aldeehani T (1995) An Implementation of Altman's Model for the prediction of corporate bankruptcy. King Abudelaziz University, Jeddah.

AlShebani W (2006) An initial role in accounting information by predicting financial failure for Saudi Companies. Journal of Administrative Sciences

Altman E (2006) Corporate financial distress and bankruptcy: a complete guide to predicting \& avoiding distress and profiting from bankruptcy. Third edition (ed.), Wiley New Jersey,

Altman E (1968) Financial ratios, discriminant analysis and the prediction of corporate bankruptcy. The Journal of finance 23, 589-609.

Altman E, Haldeman R, and Narayanan P (1977) ZETA analysis A new model to identify bankruptcy risk of corporations. Journal of Banking \& Finance 1, 29-54.

Altman EI (1983) Why businesses fail. Journal of Business Strategy 3, 15-21.

Altman EI and Lavallee M (1981) Business failure classification in Canada. Journal of Business Administration 12, 147-64.

Altman EI and Narayanan P (1997) An international survey of business failure classification models. Financial Markets, Institutions \& Instruments 6, 1-57.

Andreev Y (2006) Predicting financial distress of spanish companies.

Arabie P, Carroll DJ, and DeSarbo WS (1987) Three-way scaling and clustering. Sage, London.

Arouri MEH, Lahiani A, and Nguyen DK (2011) Return and volatility transmission between world oil prices and stock markets of the GCC countries. Economic Modelling 28, 1815-25.

Aziz A, Emanuel DC, and Lawson GH (1988) Bankruptcy prediction- an investigation of cash flow based models. Journal of Management Studies 25, 419-37.

Aziz A and Lawson GH (1989) Cash flow reporting and financial distress models: Testing of hypotheses. Financial Management 55-63.

Back B, Laitinen T, and Sere K (1996) Neural networks and genetic algorithms for bankruptcy predictions. Expert Systems with Applications 11, 407-13. 
Balcaen S and Ooghe H (2006) 35 years of studies on business failure: an overview of the classic statistical methodologies and their related problems. The British Accounting Review 38, 63-93.

Barnes P (1987) The analysis and use of financial ratios: a review article. Journal of Business Finance \& Accounting 14, 449-61.

Basheikh A, M. (2012) Prediction of financial failure of Saudi listed companies. International Journal of Managerial and Financial Accounting 4, 195-213.

Beaver W (1966) Financial ratios as predictors of failure. Journal of Accounting Research 71-111.

Bley J (2011) Are GCC stock markets predictable? Emerging markets review 12, 217 37.

Blum M (1974) Failing company discriminant analysis. Journal of Accounting Research 1-25.

Bose I (2006) Deciding the financial health of dot-coms using rough sets. Information \& management 43, 835-46.

Bragg SM (2002) Business ratios and formulas: a comprehensive guide. Wiley, London.

Breiman L (1996) Bagging predictors. Machine Learning 24, 123-40.

Brigham EF and Ehrhardt MC (2010) Financial management theory and practice. South-Western Publishing Group, Nashville, TN.

Busing FM, Groenen PJ, and Heiser WJ (2005) Avoiding degeneracy in multidimensional unfolding by penalizing on the coefficient of variation. Psycometrika 70, 71-98.

Canbas S, Cabuk A, and Kilic SB (2005) Prediction of commercial bank failure via multivariate statistical analysis of financial structures: the Turkish case. European Journal of Operational Research 166, 528-46.

Casey C and Bartczak N (1985) Using operating cash flow data to predict financial distress: some extensions. Journal of Accounting Research 23, 384-401.

CFA institute (2009) Finiacial Reporting and Analysis. PEARSON, Boston.

Charan R, Useem J, and Harrington A (2002) Why companies fail CEOs offer every excuse but the right one: their own errors. Here are ten mistakes to avoid. FORTUNE-EUROPEAN EDITION- 145, 36-46.

Charitou A, Neophytou E, and Charalambous C (2004) Predicting corporate failure: empirical evidence for the UK. European Accounting Review 13, 465-97.

Chen KH and Shimerda TA (1981) An Empirical-Analysis of Useful Financial Ratios. Financial Management 10, 51-60. 
Chipulu M, Neoh JG, Ojiako U, and Williams T (2013) A Multidimensional Analysis of Project Manager Competences. IEEE Transactions on Engineering Management 60, 506-17.

Coats PK and Fant LF (1993) Recognizing Financial Distress Patterns Using a NeuralNetwork Tool. Financial Management 22, 142-55.

Dambolena IG and Khoury SJ (2012) Ratio stability and corporate failure. The Journal of finance 35, 1017-26.

Deakin E (1972) A discriminant analysis of predictors of business failure. Journal of Accounting Research 167-79.

Doumpos M, Zopounidis C, and Golfinopoulou V (2007) Additive Support Vector Machines for Pattern Classification. Systems, Man, and Cybernetics, Part B: Cybernetics, IEEE Transactions on 37, 540-50.

Edmister RO (1972) An empirical test of financial ratio analysis for small business failure prediction. Journal of Financial and Quantitative Analysis 1477-93.

Elam R (1975) The effect of lease data on the predictive ability of financial ratios. The Accounting Review 50, 25-43.

Emery DR, Barron FH, and Messier WF (1982) Conjoint measurement and the analysis of noisy data: a comment. Journal of Accounting Research 20, 450-8.

Ezzamel M, Mar Molinero C, and Beech A (1987) On the distributional properties of financial ratios. Journal of Business Finance \& Accounting 14, 463-81.

Fasano U and Zubair I (2003) GCC Countries: from oil dependence to diversification International Monetary Fund,

Fedenczuk LL (2003) To neural or not to neural? - This is the question. In System. SUGI'27 Proceedings. (ed.), Vol. Paper 113-27, pp. Cary, NC: SAS Institute Inc.

Friedman JH (1977) A recursive partitioning decision rule for nonparametric classification. Computers, IEEE Transactions on 100, 404-8.

Furnival GM and Wilson RW (1974) Regression by Leaps and Bounds. Technometrics, 16, 499-511.

Gentry JA, Newbold P, and Whitford DT (1985) Classifying bankrupt firms with funds flow components. Journal of Accounting research 23, 146-60.

Gentry JA, Newbold P, and Whitford DT (1987) Funds flow components, financial ratios, and bankruptcy. Journal of Business Finance \& Accounting 14, 595-606.

Gilbert LR, Menon K, and Schwartz KB (1990) Predicting bankruptcy for firms in financial distress. Journal of Business Finance \& Accounting 17, 161-71.

Gloubos G and Grammatikos T (1988) The success of bankruptcy prediction models in Greece. Studies in Banking and Finance 7, 37-46. 
Gombola MJ and Ketz JE (1983) Financial Ratio Patterns in Retail and Manufacturing Organizations. Financial Management 12, 45-56.

Goudie AW and Meeks G (1991) The exchange rate and company failure in a macromicro model of the UK company sector. The Economic Journal 101, 444-57.

Gupta MC and Huefner RJ (1972) A cluster analysis study of financial ratios and industry characteristics. Journal of Accounting Research 77-95.

Han L, Han L, and Zhao H (2013) Orthogonal support vector machine for credit scoring. Engineering Applications of Artificial Intelligence 26, 848-62.

Hanley JA and McNeil BJ (1982) The meaning and use of the area under a receiver operating characteristics curve. Radiology 143, 29-36.

Hasabo H (1987) The Use of Accounting ratios in Predicting financial crises a Suggested Model For Kuwait Stock Exchange. Journal of the Gulf and Arabian Peninsular States Studies 13

Hawkins DM (2004) The problem of overfitting. Journal of chemical information and computer sciences $44,1-12$.

House RJ, Hanges PJ, Javidan M, Dorfman PW, and Gupta V (2004) Culture, Leadership and Organizations : The GLOBE Study of 62 Societies. In (ed.), Vol. pp. Thousand Oaks CA, Sage.,

Hussain M, Islam MM, Gunasekaran A, and Maskooki K (2002) Accounting standards and practices of financial institutions in GCC countries. Managerial Auditing Journal 17, 350-62.

Jones FL (1987) Current techniques in bankruptcy prediction. Journal of accounting Literature 6, 131-64.

Jones S and Hensher DA (2004) Predicting firm financial distress: a mixed logit model. The Accounting Review 79, 1011-38.

Joy OM and Tollefson JO (1975) On the financial applications of discriminant analysis. Journal of Financial and Quantitative Analysis 723-39.

Karels GV and Prakash AJ (1987) Multivariate normality and forecasting of business bankruptcy. Journal of Business Finance \& Accounting 14, 573-93.

Keasey K and McGuinness P (1990) The failure of UK industrial firms for the period 1976-1984, logistic analysis and entropy measures. Journal of Business Finance \& Accounting 17, 119-35.

Khamis M and Senhadji A (2010) Impact of the Global Financial Crisis on the Gulf Cooperation Council Countries and Challenges Ahead. In (ed.), Vol. pp. International Monetary Fund, Washington, DC.

Ko C (1982) A delineation of corporate appraisal models and classification of bankruptcy firms in Japan. New York University, thesis

Kruskal JB and Wish M (1978) Multidimensional Scaling. Sage, London. 
Kuwait stock exchange (2010) KSE Committ decision No. (3/2010). In (ed.), Vol. 2011, pp.

Laitinen T and Kankaanpaa M (1999) Comparative analysis of failure prediction methods: the Finnish case. European Accounting Review 8, 67-92.

Lane WR, Looney SW, and Wansley JW (1986) An application of the Cox proportional hazards model to bank failure. Journal of Banking \& Finance 10, 511-31.

Lensberg T, Eilifsen A, and McKee TE (2006) Bankruptcy theory development and classification via genetic programming. European Journal of Operational Research 169, 677-97.

Libby R (1975) Accounting Ratios and the Prediction of Failure: some behavioral evidence. Journal of Accounting Research 150-61.

Luoma M and Laitinen EK (1991) Survival analysis as a tool for company failure prediction. Omega 19, 673-8.

Mar-Molinero C and Serrano-Cinca C (2001) Bank failure: a multidimensional scaling approach. The European Journal of Finance 7, 165-83.

Mar Molinero C and Ezzamel M (1991) Multidimensional scaling applied to corporate failure. Omega 19, 259-74.

Megginson WL and Smart SB (2005) Introduction to corporate finance. Cengage Learning,

Mensah YM (1983) The differential bankruptcy predictive ability of specific price level adjustments: Some empirical evidence. Accounting Review 228-46.

Mensah YM (1984) An examination of the stationarity of multivariate bankruptcy prediction models: a methodological study. Journal of Accounting Research 380-95.

Min JH and Lee Y-C (2005) Bankruptcy prediction using support vector machine with optimal choice of kernel function parameters. Expert Systems with Applications 28, 603-14.

Ministry of Industry and Commerce Kingdom of Bahrain (2002) Commercial Registration - Law No. 9, 2002. In (ed.), Vol. pp.

Moriarity S and Barron FH (1976) Modeling the Materiality Judgements of Audit Partners. Journal of Accounting Research 320-41.

Morris R (1997) Early Warning Indicators of Corporate Failure: A critical review of previous research and further empirical evidence. Ashgate, England

Moyer RC, McGuigan JR, and Kretlow WJ (2008) Contemporary financial management. South-Western Publishing, Nashville, TN.

Neophytou E and Molinero C (2005) Financial Ratios, Size, Industry and Interest Rate Issues in Company Failure: An Extended Multidimensional Scaling Analysis. In (ed.), Vol. pp. Kent Business School. 
Neophytou E and Molinero C (2004a) Predicting corporate failure in the UK: a multidimensional scaling approach. Journal of Business Finance \& Accounting 31, 677-710.

Neophytou E and Molinero C (2004b) Predicting corporate failure in the UK: a multidimensional scaling approach. Journal of Business Finance \& Accounting 31, 677-710.

Ohlson JA (1980) Financial ratios and the probabilistic prediction of bankruptcy. Journal of Accounting Research 18, 109-31.

Ong CS, Huang JJ, and Tzeng GH (2005) Building credit scoring models using genetic programming. Expert Systems with Applications 29, 41-7.

Onour I (2010) The Global Financial Crisis and Equity Markets in Middle East Oil Exporting Countries. In (ed.), Vol. pp. The Arab Planning Institute, Kuwait.

Peduzzi P, Concato J, Kemper E, Holford TR, and Feinstein AR (1996) A simulation study of the number of events per variable in logistic regression analysis. Journal of clinical epidemiology 49, 1373-9.

Peel M, Peel D, and Pope P (1986) Predicting corporate failure-some results for the UK corporate sector. Omega 14, 5-12.

Peeters M (2011) The changing pattern in international trade and capital flows of the Gulf Cooperation Council countries in comparison with other oil-exporting countries. Journal of Knowledge Management, Economics and Information Technology 1, 356-84.

Platt HD and Platt MB (1990) Development of a class of stable predictive variables: the case of bankruptcy prediction. Journal of Business Finance \& Accounting 17, 31-51.

Punj G and Stewart DW (1983) Cluster analysis in marketing research: review and suggestions for application. Journal of Marketing Research 134-48.

Ravisankar P, Ravi V, and Bose I (2010) Failure prediction of dotcom companies using neural network-genetic programming hybrids. Information Sciences 180, 125767.

Richardson FM and Davidson LF (1983) An exploration into bankruptcy discriminant model sensitivity. Journal of Business Finance \& Accounting 10, 195-207.

Rocha R and Farazi S (2011) Financial Access and Stability. In Financial Flagship Report. Report MPSDF (ed.), (ed.), Vol. pp. 362, World Bank, Washington,DC.

Salchenberger LM, Cinar E, and Lash NA (1992) Neural Networks: A New Tool for Predicting Thrift Failures*. Decision Sciences 23, 899-916.

Saudi Commerce Ministry (1966) Systems and Regulations - Companies System In (ed.), Vol. 2011, pp. 
Schiffman S, Reynolds M, and Young F (1981) Introduction to Multidimensional Scaling Theory, Methods and Applications. Academic Press, London.

Serrano-Cinca C (1996) Self organizing neural networks for financial diagnosis. Decision Support Systems 17, 227-38.

Shin KS and Lee YJ (2002) A genetic algorithm application in bankruptcy prediction modeling. Expert Systems with Applications 23, 321-8.

Shumway T (2001) Forecasting bankruptcy more accurately: A simple hazard model*. The Journal of Business 74, 101-24.

Smith M and Liou DK (1979) Industrial sector and financial distress. Managerial Auditing Journal 22, 376-91.

Sori M and Hasbullah J (2009) Financial ratios, discriminant analysis and the prediction of corporate distress. Cognitive Science 11, 5-15.

State of Qatar Ministry of Economy and Commerce (2002) The Commercial Companies Law - Law No. (5) of 2002. In (ed.), Vol. 5, pp.

Steyerberg EW, Eijkemans MJC, Harrell FE, and Habbema JDF (2001) Prognostic Modeling with Logistic Regression Analysis: In Search of a Sensible Strategy in Small Data Sets. Medical Decision Making 21, 45-56.

Sultanate of Oman Ministry of Commerce and Industry (1986) Laws and RegulationsCommercial Companies law. In (ed.), Vol. No. 4/74, pp.

Sung TK, Chang N, and Lee G (1999) Dynamics of modeling in data mining: interpretive approach to bankruptcy prediction. Journal of Management Information Systems 16, 63-85.

Ta HP and Seah LH (1988) Business failure prediction in Singapore. Studies in Banking and Finance 7, 105-13.

Taffler R (1982) Forecasting company failure in the UK using discriminant analysis and financial ratio data. Journal of the Royal Statistical Society. Series A (General) 145, 342-58.

Thomas LC, Edelman DB, and Crook JN (2002) Credit scoring and its applications. Siam,

United Arab Emirate Ministry of Economy (1984) Commercial Regulations Companies Law. In (ed.), Vol. 8, pp.

Uttamchandani M, Nasser SN, Batra S, Sanderson R, Koldertsova A, and Helmy O (2009) Study on Insolvency Systems in the middle east and north Africa. Hawkamah/World Bank/OECD/INSOL International,

Varetto F (1998) Genetic algorithms applications in the analysis of insolvency risk. Journal of Banking \& Finance 22, 1421-39. 
Ward TJ (1994) Cash flow information and the prediction of financially distressed mining, oil and gas firms: a comparative study. Journal of Applied Business Research (JABR) 10, 78-86.

Warner JB (1977) Bankruptcy costs: Some evidence. The Journal of finance 32, 337-47.

White M (1996) The costs of corporate bankruptcy: A US-European comparison. Corporate bankruptcy: Economic and legal perspectives 467-500.

Wilcox J (1973) A prediction of business failure using accounting data. Journal of Accounting Research 163-79.

Zavgren C (1985) Assessing the vulnerability to failure of American industrial firms: a logistic analysis. Journal of Business Finance \& Accounting 12, 19-45.

Zavgren C (1983) The prediction of corporate failure: the state of the art. Journal of Accounting Literature 2, 1-37.

Zhu X, Li J, Wu D, Wang H, and Liang C (2013) Balancing accuracy, complexity and interpretability in consumer credit decision making: A C-TOPSIS classification approach. Knowledge-Based Systems 52, 258-67.

Zmijewski ME (1984) Methodological issues related to the estimation of financial distress prediction models. Journal of Accounting Research 22, 59-82. 


\section{Appendix I: Sample of Insolvent and Solvent Firms}

\begin{tabular}{|c|c|c|c|c|}
\hline \multicolumn{3}{|l|}{ Insolvent firms } & \multicolumn{2}{|l|}{ Solvent Firms } \\
\hline Companies & size of Assets & $\begin{array}{l}\text { year of } \\
\text { failure }\end{array}$ & Companies & Size of Assets \\
\hline Middle East Specialized Cables Co & 367,808 & 2011 & Al hassan Ghazi Ibrahim & 323,171 \\
\hline Ethihad Atheeb & 563,439 & 2011 & Etihad etisalat & $10,000,180$ \\
\hline Anaam & 65,314 & 2006 & Herfy Food Services & 72,647 \\
\hline Saudi Fisheries Co & 43,213 & 2005 & Al Sharqiyah & 38,049 \\
\hline Aseer Trading & 882,461 & 2008 & National co & 130,075 \\
\hline Saudi Transeport Mobarad & 47,065 & 2011 & United international & 267,459 \\
\hline Banader Hotels & 26,624 & 2009 & Bahrain Family & 11,889 \\
\hline Medicare group & 132,779 & 2006 & Gulf international & 589,687 \\
\hline Mushrif Trading Contracting & 368,493 & 2008 & Combined group & 465,433 \\
\hline National Ind & 466,163 & 2008 & Mabanee co & 854,885 \\
\hline Portland Cement & 200,478 & 2008 & United projects & 159,474 \\
\hline National Ranges & 476,852 & 2008 & Kuwait cement co KSC & 886,607 \\
\hline Human Soft Holding & 44,510 & 2006 & Safwan trading & 47,797 \\
\hline Gulf franchising & 40,776 & 2009 & Hayat communi Holding & 66,176 \\
\hline Nafais Holding & 480,972 & 2009 & Advanced technology & 273,283 \\
\hline Sultan center food & $1,085,362$ & 2010 & Gulf cable & $1,143,807$ \\
\hline Kuwait Cable Vision & 21,041 & 2010 & Automated systems co & 37,162 \\
\hline Educational Holding & 208,431 & 2010 & Alsafat tec holding & 211,376 \\
\hline Livestock transport and trading co & 168,800 & 2011 & Danah Al safat & 183,004 \\
\hline Shuaiba Ind & 62,469 & 2006 & National metal & 116,991 \\
\hline Heavy Eng and Ship Building & 205,348 & 2006 & Arabian pipes co & 336,815 \\
\hline Equipment Holding & 130,710 & 2009 & Saudi steel pipe & 261,634 \\
\hline Kuwait Founding & 181,721 & 2011 & Takween & 215,259 \\
\hline Kuwait Pipe Ind and Oil Ser & 824,718 & 2011 & Saudi arabian mining & $11,619,660$ \\
\hline Mubarrad transport & 101,403 & 2009 & KGL logistics co & 205,000 \\
\hline Jazeera airways & 254,269 & 2009 & Alafco Aviation & $1,345,621$ \\
\hline Refrigeration & 79,103 & 2009 & Saudi Public & 484,156 \\
\hline City group & 111,664 & 2011 & National shipping & $2,832,856$ \\
\hline Kuwait Gulf Link Transport & 694,379 & 2011 & Agility Public & $4,835,941$ \\
\hline
\end{tabular}




\begin{tabular}{|c|c|c|c|c|}
\hline Ikarus Petroleum Ind & 412,833 & 2008 & Aref Energy & 431,933 \\
\hline Gulf Petro Invest & 198,903 & 2009 & Al safat En. Holding & 284,355 \\
\hline Independent Petro & $1,516,646$ & 2011 & Boubyan Pet & $1,535,243$ \\
\hline IFA Hotels and Resorts & $1,382,245$ & 2010 & Kuwait national & 240,845 \\
\hline Kuwait Hotels & 51,624 & 2010 & Future Kid entertain & 81,631 \\
\hline Mashaer Holding & 255,200 & 2010 & Kuwait resorts co & 203,741 \\
\hline Oman Filters Ind & 5,795 & 2006 & Oman Chromite & 6,032 \\
\hline National Aluminium pro & 52,271 & 2008 & Majan Glass & 40,882 \\
\hline A Saffa foods & 39,829 & 2005 & Areej Vegtable Oils and Deriv & 46,039 \\
\hline Oman National Dairy & 13,287 & 2007 & Omani Euro foods internaties & 15,232 \\
\hline Sohar poultry & 24,337 & 2007 & Oman Refreshment & 49,287 \\
\hline Dhofar Beverages and Food stuff & 8,987 & 2008 & Sweets of Oman & 9,634 \\
\hline National beverages & 20,624 & 2008 & National Biscuit ind & 20,534 \\
\hline National mineral water & 31,976 & 2010 & Oman Fisheries & 43,974 \\
\hline Dhofar Fisheries & 17,976 & 2011 & Salalah Flour Mills & 128,126 \\
\hline Oman Agriculture & 15,521 & 2011 & Oman Foods Ind & 11,347 \\
\hline National Detergent & 26,539 & 2005 & Al Anwar ceramic & 29,071 \\
\hline Cement and Gypsum Pro & 5,289 & 2007 & Al oula company saog & 5,939 \\
\hline Al Jazeira services & 61,742 & 2008 & Oman investment & 83,316 \\
\hline Oman international & 5,976 & 2009 & Computer stationery & 12,384 \\
\hline National Hospitality & 1,918 & 2010 & Muscat Thread mills & 6,468 \\
\hline Dhorar Tourism & 213,497 & 2010 & Gulf Hotels oman & 86,771 \\
\hline United Foods & 59,266 & 2008 & Dubai Refreshments & 97,729 \\
\hline Jeema mireral water & 24,602 & 2010 & Gulfa Mineral water and industrual prod & 14,769 \\
\hline United Kaiparpa Dairies & 48,977 & 2011 & Food Products Co & 58,773 \\
\hline National central cooling & $2,101,698$ & 2009 & Arabtec Holding & $2,482,415$ \\
\hline Damas & $1,101,044$ & 2010 & Arab heavy ind & 62,881 \\
\hline
\end{tabular}




\section{Appendix II : Logit Prediction Model Results}

\begin{tabular}{|l|l|l|l|}
\hline R-Square & 0.6281 & Max-rescaled R-Square & 0.8375 \\
\hline
\end{tabular}

\begin{tabular}{|l|r|r|r|}
\hline \multicolumn{4}{|c|}{ Testing Global Null Hypothesis: BETA=0 } \\
\hline Test & Chi-Square & DF & Pr $>$ ChiSq \\
\hline Likelihood Ratio & 65.2891 & 4 & $<.0001$ \\
\hline Score & 40.8480 & 4 & $<.0001$ \\
\hline Wald & 13.5829 & 4 & 0.0088 \\
\hline
\end{tabular}

\begin{tabular}{|l|r|r|r|r|r|}
\hline \multicolumn{7}{|c|}{ Analysis of Maximum Likelihood Estimates } \\
\hline Parameter & DF & Estimate & $\begin{array}{r}\text { Standard } \\
\text { Error }\end{array}$ & $\begin{array}{r}\text { Wald } \\
\text { Chi-Square }\end{array}$ & Pr > ChiSq \\
\hline Intercept & 1 & -0.7652 & 0.6856 & 1.2459 & 0.2643 \\
\hline EBITTL & 1 & -7.3046 & 2.1068 & 12.0208 & 0.0005 \\
\hline TLTA & 1 & 0.7776 & 0.3726 & 4.3545 & 0.0369 \\
\hline CFFOTA & 1 & -55.5799 & 17.3161 & 10.3023 & 0.0013 \\
\hline CFFOCL & 1 & 8.0985 & 2.5743 & 9.8969 & 0.0017 \\
\hline
\end{tabular}

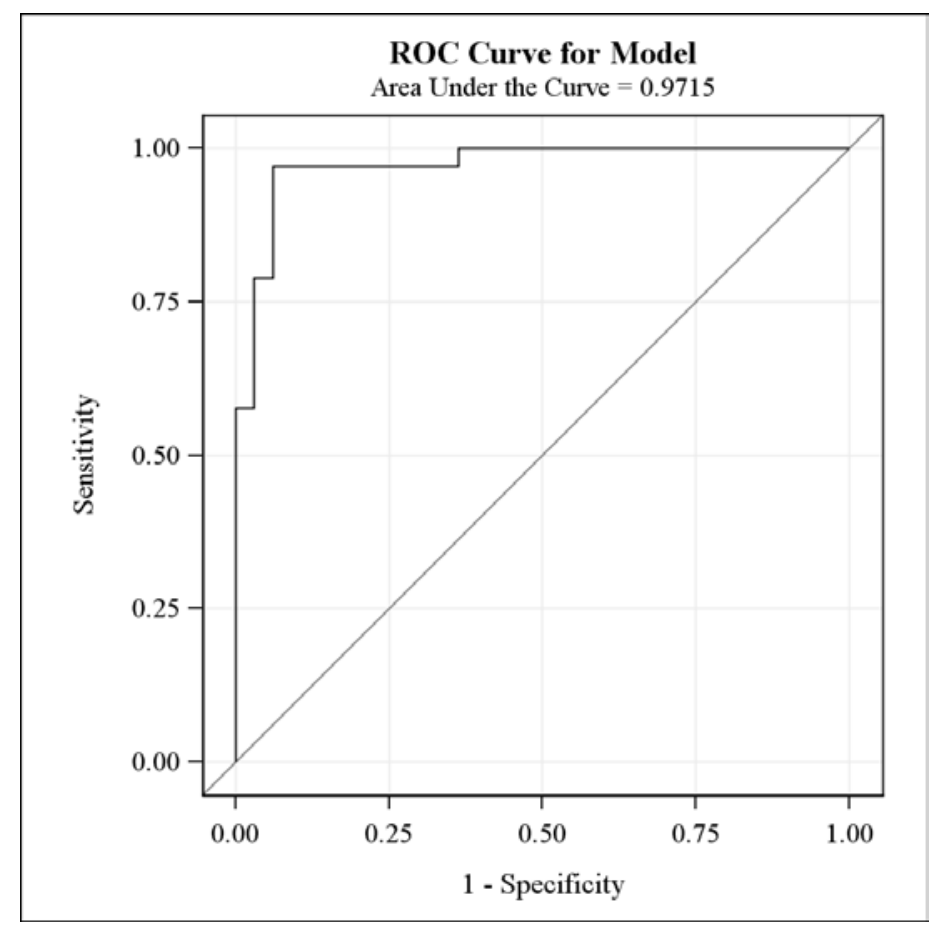

\begin{tabular}{|l|l|l|l|l|}
\hline \multicolumn{4}{|c|}{ Classification Matrix } \\
\hline \multicolumn{2}{|c|}{} & Observed Frequencies & \multirow{2}{*}{ Total number } \\
\cline { 3 - 5 } \multicolumn{2}{|c|}{ Solvent } & Insolvent & \\
\hline \multirow{2}{*}{$\begin{array}{l}\text { Predicted } \\
\text { Frequencies }\end{array}$} & Solvent & 17 & 1 & 18 \\
\cline { 2 - 5 } & Insolvent & 6 & 22 & 28 \\
\hline Total number & 23 & 23 & 46 \\
\hline
\end{tabular}


Appendix III: Probit Prediction Model Results

\begin{tabular}{|l|l|l|l|}
\hline R-Square & 0.6264 & Max-rescaled R-Square & 0.8352 \\
\hline
\end{tabular}

\begin{tabular}{|l|r|r|r|}
\hline \multicolumn{4}{|c|}{ Testing Global Null Hypothesis: BETA=0 } \\
\hline Test & Chi-Square & DF & Pr $>$ ChiSq \\
\hline Likelihood Ratio & 64.9763 & 4 & $<.0001$ \\
\hline Score & 40.8480 & 4 & $<.0001$ \\
\hline Wald & 16.6675 & 4 & 0.0022 \\
\hline
\end{tabular}

\begin{tabular}{|l|r|r|r|r|r|}
\hline \multicolumn{7}{|c|}{ Analysis of Maximum Likelihood Estimates } \\
\hline Parameter & DF & Estimate & $\begin{array}{r}\text { Standard } \\
\text { Error }\end{array}$ & $\begin{array}{r}\text { Wald } \\
\text { Chi-Square }\end{array}$ & Pr > ChiSq \\
\hline Intercept & 1 & -0.4884 & 0.3607 & 1.8327 & 0.1758 \\
\hline EBITTL & 1 & -3.9123 & 1.0173 & 14.7909 & 0.0001 \\
\hline TLTA & 1 & 0.4518 & 0.1913 & 5.5763 & 0.0182 \\
\hline CFFOTA & 1 & -31.3039 & 8.7092 & 12.9194 & 0.0003 \\
\hline CFFOCL & 1 & 4.5717 & 1.2904 & 12.5510 & 0.0004 \\
\hline
\end{tabular}

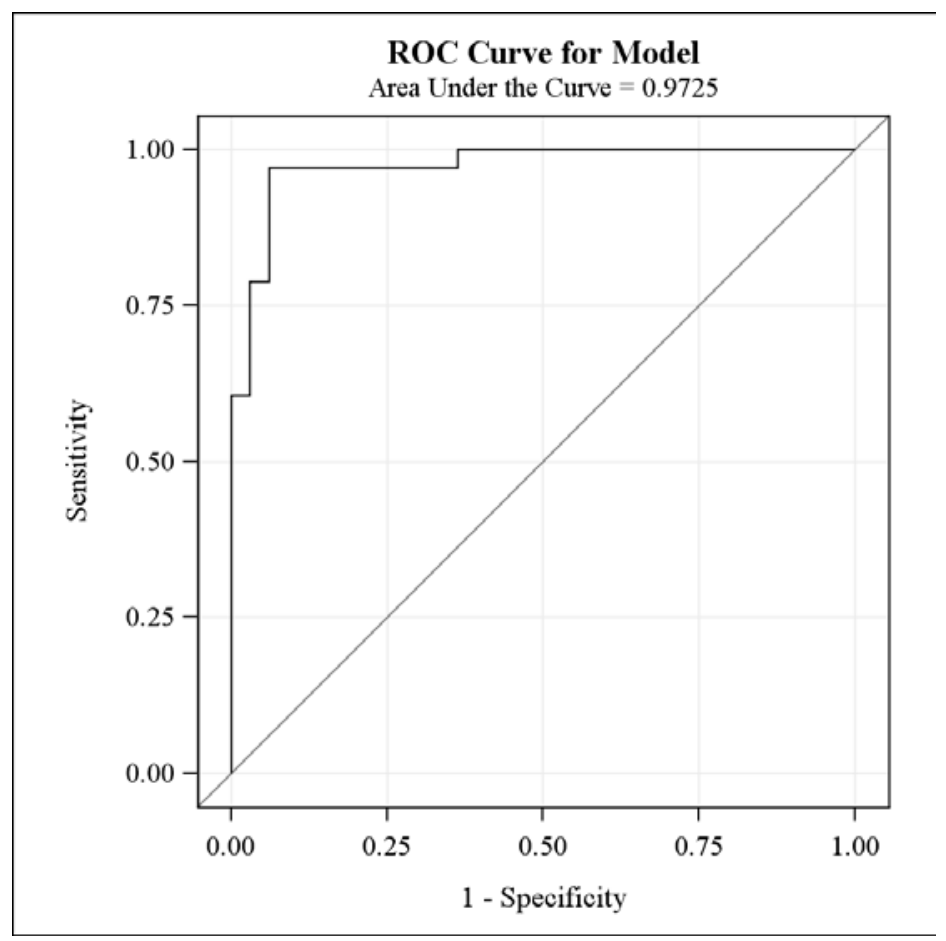

\begin{tabular}{|l|l|l|l|l|}
\hline \multicolumn{4}{|c|}{ Classification Matrix } & \multirow{2}{*}{ Total number } \\
\cline { 3 - 5 } \multicolumn{2}{|c|}{ Observed Frequencies } & \\
\hline \multirow{2}{*}{$\begin{array}{l}\text { Predicted } \\
\text { Frequencies }\end{array}$} & Solvent & Insolvent & \\
\cline { 2 - 5 } & Insolvent & 6 & 17 & 18 \\
\hline Total number & 23 & 22 & 28 \\
\hline
\end{tabular}




\section{Appendix IV: Significance of Financial Ratios Across Insolvency Studies}

\begin{tabular}{|c|c|c|c|c|c|c|c|c|c|c|c|c|c|c|c|c|c|c|c|c|c|c|c|c|c|c|c|c|c|c|}
\hline \multirow[b]{2}{*}{\begin{tabular}{|l} 
\\
$\begin{array}{l}\text { Details of } \\
\text { Studies }\end{array}$
\end{tabular}} & \multirow[b]{2}{*}{$\begin{array}{l}\text { Data } \\
\text { Location }\end{array}$} & \multirow[b]{2}{*}{ Method } & \multicolumn{5}{|c|}{ Profitability } & \multicolumn{6}{|c|}{ Leverage } & \multicolumn{3}{|c|}{ Liquidity } & \multicolumn{6}{|c|}{ Activity } & \multicolumn{6}{|c|}{ Cash Flow } & \multicolumn{2}{|c|}{ Market } \\
\hline & & & 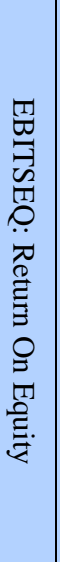 & 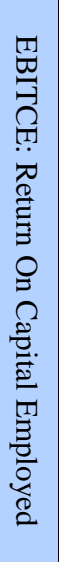 & 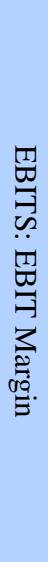 & 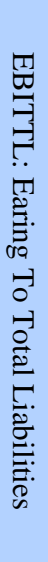 & $\begin{array}{l}0 \\
0 \\
3 \\
0 \\
0 \\
0 \\
0 \\
0 \\
0 \\
0 \\
0 \\
0 \\
3 \\
0 \\
0 \\
0.0 \\
0 .\end{array}$ & 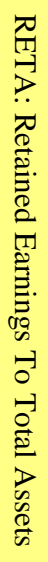 & 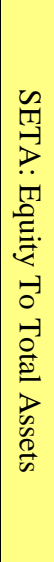 & 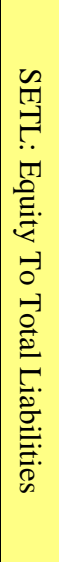 & 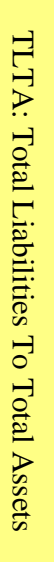 & 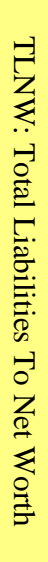 & 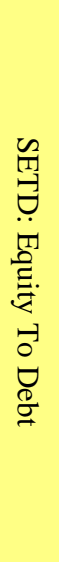 & 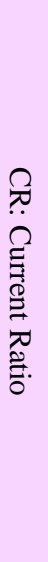 & 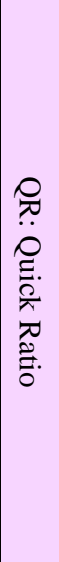 & 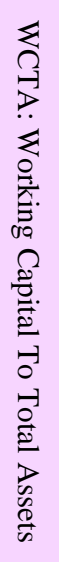 & 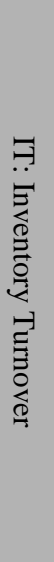 & 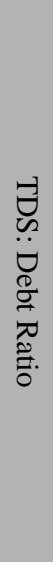 & 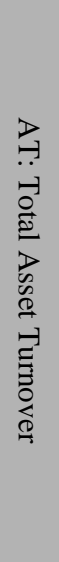 & 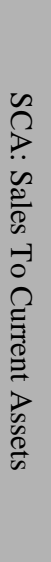 & 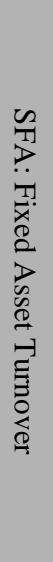 & 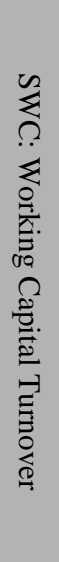 & 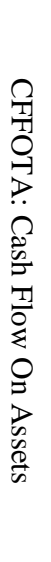 & 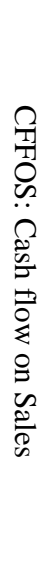 & 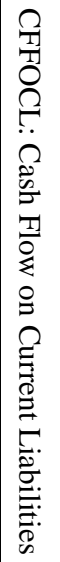 & 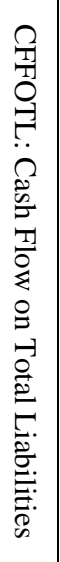 & 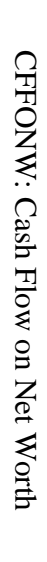 & 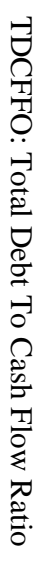 & 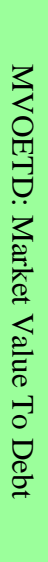 & 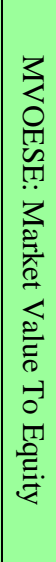 \\
\hline $\begin{array}{l}\text { Current } \\
\text { Study } \\
\end{array}$ & GCC & Logit & & & & $\mathbf{X}$ & & & & & $\mathbf{X}$ & & & & & & & & & & & & $\mathbf{X}$ & & $\mathbf{X}$ & & & & & \\
\hline $\begin{array}{l}\text { Basheikh } \\
\text { (2012) }\end{array}$ & $\begin{array}{l}\text { Saudi } \\
\text { Arabia }\end{array}$ & $\begin{array}{l}\text { Univariate } \\
\text {, MDA, } \\
\text { Logit }\end{array}$ & $\mathrm{X}$ & & & & & & & & & & & & & & & & $\mathrm{X}$ & & & & & & & & & & & \\
\hline $\begin{array}{l}\text { Ong et al. } \\
\text { (2005) }\end{array}$ & Malaysia & Logistic & & & & & & & & & & & & $\mathrm{X}$ & & & & & $\mathrm{X}$ & $\mathrm{X}$ & & & & & & & & & & \\
\hline $\begin{array}{l}\text { Ravisanka } \\
\text { r et al. } \\
(2010)\end{array}$ & $\begin{array}{l}\text { Internation } \\
\text { al: Dot- } \\
\text { Com } \\
\text { Firms } \\
\end{array}$ & $\begin{array}{l}\text { Neural } \\
\text { Networks }\end{array}$ & & & & & & $\mathrm{X}$ & & & & & & & & & & & & & & & $\mathrm{X}$ & $\mathrm{X}$ & & & & & & \\
\hline $\begin{array}{l}\text { Sori and } \\
\text { Hasbullah } \\
(2009)\end{array}$ & Singapore & $\begin{array}{l}\text { Discrimin } \\
\text { ant } \\
\text { Analysis } \\
\end{array}$ & & & & & & & & & & & & & & & & & & & & & & $\mathrm{X}$ & & & & & & \\
\hline $\begin{array}{l}\text { Bose } \\
(2006)\end{array}$ & $\begin{array}{l}\text { Internation } \\
\text { al: Dot- } \\
\text { Com } \\
\text { Firms } \\
\end{array}$ & $\begin{array}{l}\text { Rough } \\
\text { Sets }\end{array}$ & & & & & & $\mathrm{X}$ & & & & & & & & & & & & & & & $\mathrm{X}$ & & & & & & & \\
\hline Andreev & Spain & Neural & & & $\mathrm{X}$ & & & & & & & & & & & $\mathrm{X}$ & & & & & & & & & & & & & & \\
\hline
\end{tabular}




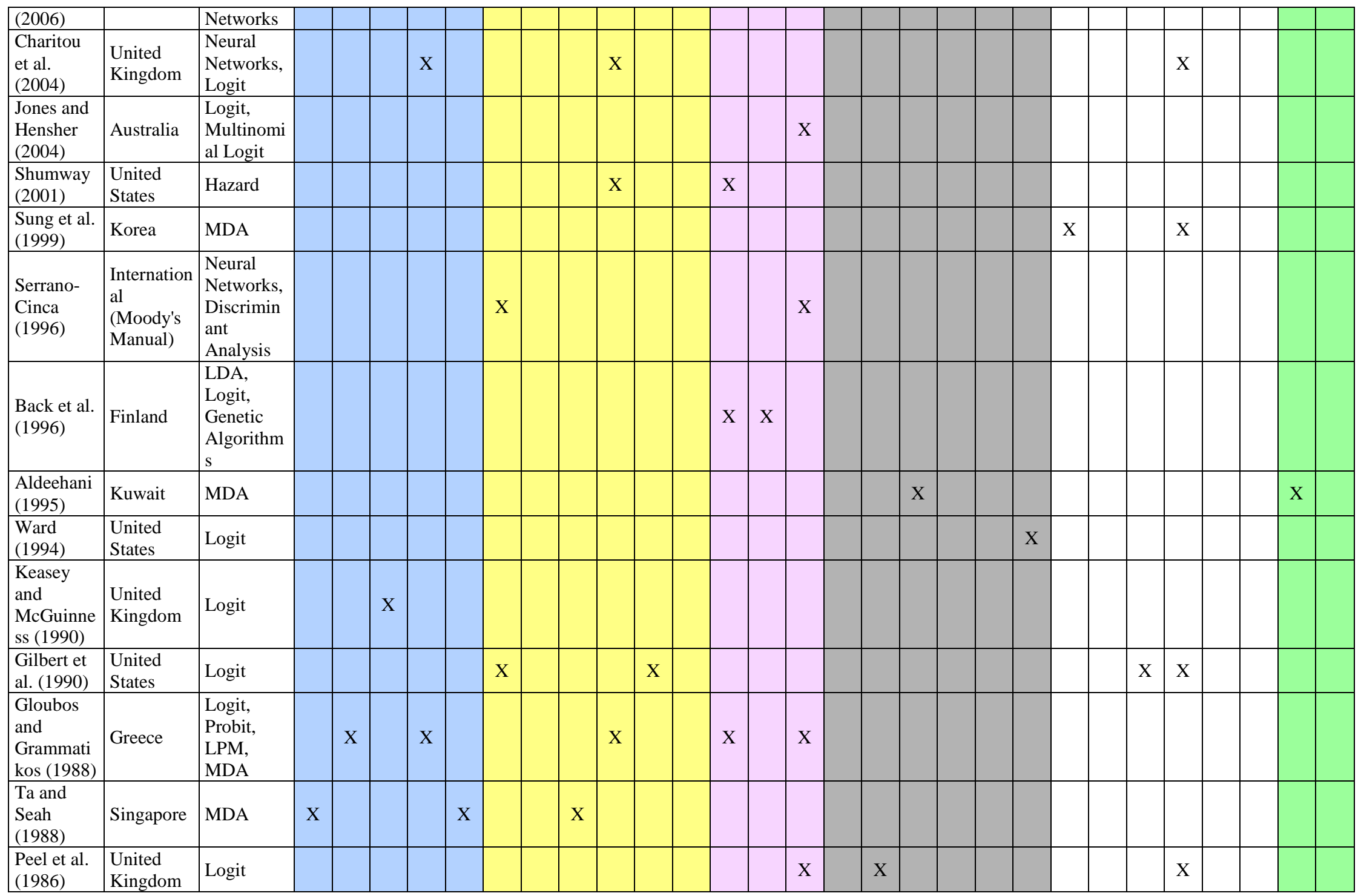




\begin{tabular}{|c|c|c|c|c|c|c|c|c|c|c|c|c|c|c|c|c|c|c|c|c|c|c|c|c|c|c|c|c|c|c|}
\hline $\begin{array}{l}\text { Zavgren } \\
\text { (1985) }\end{array}$ & \begin{tabular}{|l|} 
United \\
States
\end{tabular} & Logit & & & & & & & & & $\mathrm{X}$ & & & & $\mathrm{X}$ & & & & & & & & & & & & & & & \\
\hline $\begin{array}{l}\text { Zmijewski } \\
(1984)\end{array}$ & \begin{tabular}{|l|} 
United \\
States
\end{tabular} & Probit & & & & & & & & & $X$ & & & & & & & & & & & & & & & & & & & \\
\hline Ко (1982) & Japan & MDA & & & $\mathrm{X}$ & & & & & & & & & & & & & & & & & & & & & & & & $\mathrm{X}$ & \\
\hline $\begin{array}{l}\text { Altman } \\
\text { and } \\
\text { Lavallee } \\
(1981) \\
\end{array}$ & Canada & MDA & & & & & & & & & $\mathrm{X}$ & & & $\mathrm{X}$ & & & & & $\mathrm{X}$ & & & & & & & & & & & \\
\hline $\begin{array}{l}\text { Ohlson } \\
(1980)\end{array}$ & \begin{tabular}{|l|} 
United \\
States
\end{tabular} & Logit & & & & & & & & & $\mathrm{X}$ & & & & & $\mathrm{X}$ & & & & & & & & & & & & & & \\
\hline $\begin{array}{l}\text { Taffler } \\
(1982)\end{array}$ & $\begin{array}{l}\text { United } \\
\text { Kingdom }\end{array}$ & MDA & & & & & & & & & & & & & & & $\mathrm{X}$ & & & & & & & & & & & & & \\
\hline $\begin{array}{l}\text { Deakin } \\
(1972)\end{array}$ & \begin{tabular}{|l|} 
United \\
States
\end{tabular} & $\begin{array}{l}\text { Univarite, } \\
\text { MDA }\end{array}$ & & & & & & $\mathrm{X}$ & & & & & & $\mathrm{X}$ & $\mathrm{X}$ & $\mathrm{X}$ & & & & & & & & & & & & & & \\
\hline $\begin{array}{l}\text { Altman } \\
\text { (1968) }\end{array}$ & \begin{tabular}{|l} 
United \\
States
\end{tabular} & MDA & & & & & & $\mathrm{X}$ & & & & & & & & $X$ & & & $\mathrm{X}$ & & & & & & & & & & $X$ & \\
\hline $\begin{array}{l}\text { Beaver } \\
(1966)\end{array}$ & \begin{tabular}{|l|} 
United \\
States \\
\end{tabular} & Univariate & & & & & & & & & & & & & & $\mathrm{X}$ & & & & & & & & & & & & & & \\
\hline $\begin{array}{l}\text { Total Numbe } \\
\text { Ratios }\end{array}$ & er of Occur & ences of & 2 & 1 & 3 & 3 & 1 & 6 & 0 & 1 & 8 & 1 & 0 & 6 & 3 & 9 & 1 & 1 & 5 & 1 & 0 & 1 & 4 & 2 & 2 & 4 & 0 & 0 & 3 & 0 \\
\hline
\end{tabular}

